\title{
Studies toward the Total Synthesis of Nominine
}

\author{
Oliver E. Hutt ${ }^{* \dagger}$ and Lewis N. Mander \\ Research School of Chemistry, The Institute of Advanced Studies, The Australian National University, \\ Canberra, ACT 0200, Australia \\ huttx005@umn.edu
}

Received September 11, 2007

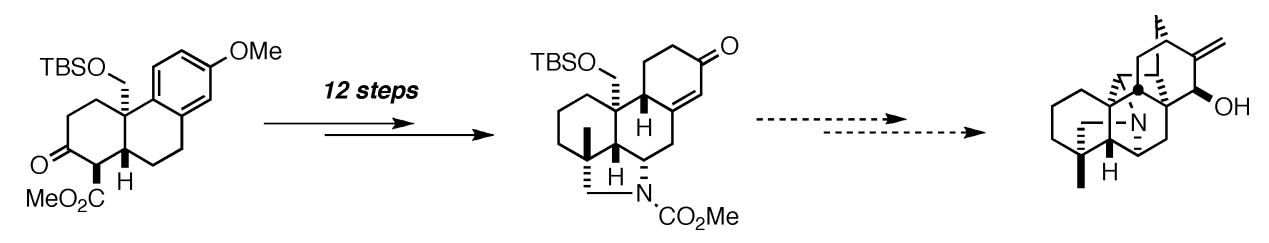

The construction of the hetisane group of alkaloids, of which the extensively bridged nominine $\mathbf{1 7}$ is the simplest member, poses the ultimate challenge for those interested in the synthesis of the $\mathrm{C}_{20}$ diterpene alkaloids. We describe the synthesis of an advanced intermediate toward this goal. The key steps include reductive acylation, reductive deoxygenation, Birch reduction, and an intramolecular Lewis acid-catalyzed 1,6 -addition of a carbamate to a dienone.

\section{Background}

The diterpene alkaloids (DAs) comprise a broad array of toxic compounds isolated from plants of the genera Aconitum, Delphiunium, Thalictrum, Consolida, and Rosera. ${ }^{1}$ The most infamous of these plants is the species Aconitum napellus, commonly known as Monkshood or wolf's bane. These plants have been used extensively in traditional medicine throughout Europe and Asia as painkillers and to reduce the increased heart rate associated with the onset of fever and anxiety. However, the narrow window in which the active constituents are effective has limited clinical applications as poisoning is an unpleasant and sometimes fatal side effect. Overdose induces a sensation of crawling skin, labored breathing, paralysis, nausea, and vomiting; ultimately, the heart goes into shock, resulting in death.

Although the diterpene alkaloids have been known for over 60 years, they are only now becoming recognized for their unique selectivity in the central nervous system. ${ }^{2}$ A survey of a cross section of these alkaloids reveals anti-arrhythmic, antiinflammatory, anti-epileptic, hypotensive, and bradycardic properties. Perhaps the most promising findings are the specific

\footnotetext{
$\dagger$ Current address: Department of Medicinal Chemistry, The University of Minnesota, 717 Delaware Street Room 482A, Minneapolis, MN 55414.

(1) (a) Wang, F.-P.; Liang, X.-T. Alkaloids (San Diego, CA, U.S.) 2002, 59, 2-280. Atta ur, R.; Choudhary, M. I. Nat. Prod. Rep. 1999, 16, 619635. Atta Ur, R.; Choudhary, M. I. Nat. Prod. Rep. 1997, 14, 191-203. Atta ur, R.; Choudhary, M. I. Nat. Prod, Rep. 1995, 12, 361-379. Wang, F. P.; Liang, X. T. Alkaloids (Academic Press) 1992, 42, 151-247; (b) Hetisine X-ray crystal structure: Przybylska, M. Acta. Crystallogr. 1963, 16, 871-876. Przybylska, M. Can. J. Chem. 1961, 40, 566-568.
}

(2) Ameri, A. Prog. Neurobiol. (Oxford) 1998, 56, 211-235. interactions of some alkaloids with the noradrenergic and cholinergic systems. While the toxicity of the most active compounds has so far limited their clinical application, less toxic derivatives are emerging that could prove to be promising drug candidates. $^{3}$

The structural elucidation of the diterpene alkaloids was initiated by Jacobs at the Rockefeller Institute and later by Wiesner at the University of New Brunswick. These pioneering efforts provided a wealth of papers, which led to systematic elucidation of the simpler alkaloids. Although the structures of the more complex alkaloids were accurately predicted, they were only finally confirmed by X-ray crystallography. ${ }^{1 \mathrm{~b}}$ From these initial studies, over 400 aconite alkaloids have now been identified, with new alkaloids continuing to be isolated.

The alkaloids can be loosely divided into two main structural groups: $\mathrm{C}_{19}$ nor-diterpenoids and the $\mathrm{C}_{20}$ diterpenoids, represented by the lycoctonitine skeleton $\mathbf{1}$ and the atisine skeleton $\mathbf{2}$, respectively (Figure 1 ). The nor-diterpenoids are related to the diterpenes via a 1,2-alkyl shift of the C8-C9 bond and the family is extended by different numbers of hydroxy groups and their derivatives - acetates, methyl ethers, and benzoates - that can occur on almost every carbon. The $\mathrm{C}_{20}$ diterpenes can be broken into two major groups based on the arrangement of the C- and D-rings. Thus, the atisine skeleton 2 possesses a bicyclo[2.2.2] octane CD-ring system, while the veatchane skeleton $\mathbf{3}$ has an ent-kaurene-type bicyclo[3.2.1]octane arrangement. Further diversity is attributed to specific connections within the basic phenanthracene skeleton. These include a C20-C14 bond

(3) Goodall, K. J.; Barker, D.; Brimble, M. A. Synlett 2005, 1809-1827. 


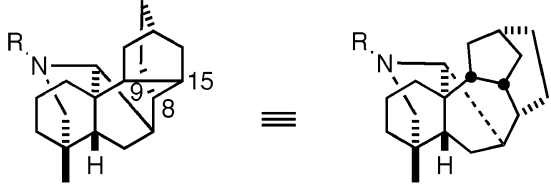

1: Lycoctonines

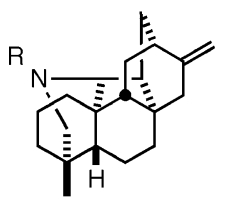

5: Hetidines

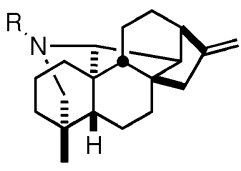

6: Anopterines

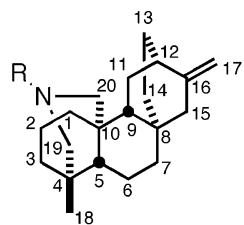

2: Atisines

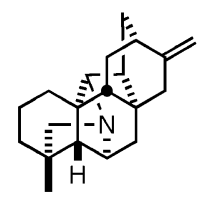

7: Hetisines

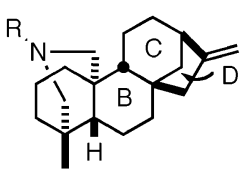

3: Veatchines

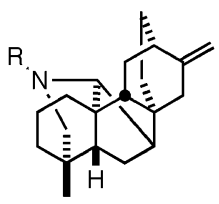

8: Denudatines

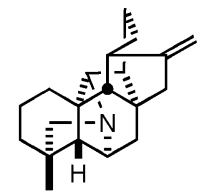

4: Delnudines

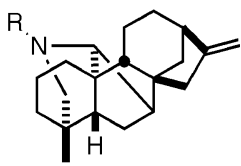

9: Napellines

FIGURE 1. Structural diversity of the diterpene alkaloid family of natural products.

(delnudines $\mathbf{4}$, hetidines $\mathbf{5}$, anopterines $\mathbf{6}$, hetisines 7), a $\mathrm{N}-\mathrm{C6}$ bond (delnudines $\mathbf{4}$, hetidines $\mathbf{5}$ ), and a $\mathrm{C} 20-\mathrm{C} 7$ bond (denudatines 8, napellines 9). Delnudines $\mathbf{4}$ also have the additional feature of a rearranged CD-ring system. Like the nor-diterpenes, the C-20 congeners are similarly characterized by extensive oxidation of the parent skeleton.

The structural complexity of the diterpene alkaloids has attracted the attention of a number of synthetic groups over the last four decades, resulting in a considerable output of elegant chemistry and useful methodology. ${ }^{4}$ The construction of the hetisine group of alkaloids, of which the extensively bridged nominine $\mathbf{1 7}$ is the simplest member, poses a daunting challenge for the $\mathrm{C}_{20}$ derivatives, but one that has been met successfully by Murutake and Natsume ${ }^{5}$ and Gin. ${ }^{6}$ Intrigued by the structural complexity of the hetisines, we initiated our own synthetic program to target these complex caged ring systems, ${ }^{7}$ which

(4) (a) Sythesis of the veatchane skeleton: Wiesner, K.; Uyeo, S.; Philipp, A.; Valenta, Z. Tetrahedron Lett. 1968, 6279-6282. Nagata, W.; Narisada, M.; Wakabayashi, T.; Sugasawa, T. J. Am. Chem. Soc. 1967, 89, 14991504. Valenta, Z.; Wiesner, K.; Wong, C. M. Tetrahedron Lett. 1964, 24372442. Nagata, W.; Narisada, M.; Wakabayashi, T.; Sugasawa, T. J. Am. Chem. Soc. 1964, 86, 929-930. Masamune, S. J. Am. Chem. Soc. 1964, 86, 290-291. (b) Synthesis of the atisane skeleton: Ihara, M.; Hirabayashi, A.; Taniguchi, N.; Fukumoto, K. Tetrahedron 1992, 48, 5089-5098. Ihara, M.; Suzuki, M.; Fukumoto, K.; Kabuto, C. J. Am. Chem. Soc. 1990, 112 1164-1171. Ihara, M.; Suzuki, M.; Fukumoto, K.; Kametani, T.; Kabuto, C. J. Am. Chem. Soc. 1988, 110, 1963-1964. Nagata, W.; Sugasawa, T.; Narisada, M.; Wakabayashi, T.; Hayase, Y. J. Am. Chem. Soc. 1967, 89, 1483-1499. Guthrie, R. W.; Valenta, Z.; Wiesner, K. Tetrahedron Lett. 1966, 4645-4654. Masamune, S. J. Am. Chem. Soc. 1964, 86, 291-292. Nagata, W.; Sugasawa, T.; Narisada, M.; Wakabayashi, T.; Hayase, Y. J. Am. Chem. Soc. 1963, 85, 2342-2343. (c) Synthesis of the napellane skeleton: Wiesner, K.; Ho, P. T.; Shii Jeou (Pan) Tsai, C.; Lam, Y. K. Can. J. Chem. 1974, 52, 2355. Wiesner, K.; Ho, P. T.; Shii Jeou (Pan) Tsai, C. Can. J. Chem. 1974, 52, 2351. (d) Synthesis of the norditerpenoids: Wiesner, K. Pure Appl. Chem. 1979, 51, 689-703. (e) Important partial syntheses: Williams, C. M.; Mander, L. N. Org. Lett. 2003, 5, 3499-3502. Kwak, Y. S.; Winkler, J. D. J. Am. Chem. Soc. 2001, 123, 7429-7430. Toyota, M.; Wada, T.; Ihara, M. J. Org. Chem. 2000, 65, 4565-4570. Shishido, K.; Hiroya, K.; Fukumoto, K.; Kametani, T. J. Chem. Soc., Chem. Commun. 1987, 1360-1361. Shibanuma, Y.; Okamoto, T. Chem. Pharm. Bull. 1985, 33, 3187-3194. Kametani, T.; Honda, T.; Fukumoto, K.; Toyota, M.; Ihara, M. Heterocycles 1981, 16, 1673-1676. Kametani, T.; Kato, Y.; Honda, T.; Fukumoto, K. J. Am. Chem. Soc. 1976, 98, 8185-8190. van der Baan, J.; Bickelhaupt, F. Recl. Trav. Chim. PaysBas 1975, 94, 109-112. Balgir, B. S.; Mander, L. N.; Prager, R. H. Aust. J. Chem. 1974, 27, 1245-1256. Tahara, A.; Hirao, K. Tetrahedron Lett. 1966, 1453-1459. Tahara, A.; Hirao, K.; Hamazaki, Y. Tetrahedron 1965, $21,2133-2154$ 4649 .

(5) Muratake, H.; Natsume, M. Angew. Chem., Int. Ed. 2004, 43, 4646-

(6) Peese, K. M.; Gin, D. Y. J. Am. Chem. Soc. 2006, 128, 8734-8735. has culminated thus far in the assembly of an advanced tetracyclic intermediate with functionality strategically placed for the rapid assembly of nominine (17), a minor constituent of Aconitum sanyoenese. ${ }^{8}$

\section{Results and Discussion}

Synthetic Plan. The preparation of enone $\mathbf{1 0}$ appeared to be an excellent starting point and its proposed elaboration into nominine (17) is outlined in Scheme 1. Thus, selective reduction of the enone with lithium in liquid ammonia was expected to establish the desired trans-fused $\mathrm{A}$ and $\mathrm{B}$ rings with trapping of the resulting enolate by methyl cynanoformate to deliver the $\beta$-keto ester 11. The $\beta$-keto ester 11 in turn could be elaborated to the amine 12. The aromatic ring of 12 would be reduced by using Birch conditions ${ }^{9}$ and the resulting 1,4-dihydroanisole converted to the enone and subsequently oxidized to the dienone 13. This strategy eliminates the need to functionalize the B-ring earlier in the synthesis. Thus, we believed that the nitrogencontaining ring would be formed through an intramolecular 1,6amino addition to give the pyrrolidine 14 . The C/D-ring would then be completed through a Sakurai allylation ${ }^{10}$ followed by a palladium-catalyzed cycloalkenylation as pioneered by Kende. ${ }^{11}$ The final bond-forming reactions would then entail an intramolecular aldol reaction $(\mathbf{1 5} \rightarrow \mathbf{1 6})$ followed by intramolecular nitrogen alkylation $(\mathbf{1 6} \rightarrow \mathbf{7})$.

Synthesis of Aldehyde 34. Our synthetic studies began (Scheme 2) with the conversion of 3-methoxyphenylacetic acid 18 into 6-methoxy-2-tetralone, ${ }^{12}$ which was subsequently acylated to give the $\beta$-keto ester 19. ${ }^{13}$ Robinson annulation with methyl vinyl ketone then gave the enone $\mathbf{2 0}$ in $67 \%$ yield. In preparation for the dissolving metal reduction, enone $\mathbf{2 0}$ was converted into the ketal 21 by using standard conditions in $99 \%$

(7) Hutt, O. E.; Mander, L. N.; Willis, A. C. Tetrahedron Lett. 2005 , $46,4569-4572$

(8) Sakai, S.; Yamamoto, I.; Yamaguchi, K.; Takayama, H.; Ito, M.; Okamoto, T. Chem. Pharm. Bull. 1982, 30 (12), 4579-4582.

(9) Mander, L. N. Synlett 1991, 134-144.

(10) Hosomi, A.; Sakurai, H. J. Am. Chem. Soc. 1977, 99, 1673-1675.

(11) (a) Kende, A. S.; Roth, B.; Sanfilippo, P. J.; Blacklock, T. J. J. Am. Chem. Soc. 1982, 104, 5808-5810. (b) Kende, A. S.; Roth, B.; Sanfilippo, P. J.; Facile, J. Am. Chem. Soc. 1982, 104, 1784-1785. (c) Toyota, M.; Ihara, M. Synlett 2002, 1211-1222.

(12) Sims, J. J.; Selman, L. H.; Cadogan, M. Organic Syntheses; Wiley: New York, 1988; Collect. Vol. VI, p 744. Sims, J. J.; Selman, L. H.; Cadogan, M. Org. Synth. 1971, 51, 109.

(13) Colvin, E. W.; Doyle, M.; Shroot, B.; Raphael, R. A.; Martin, J.; Parker, W. J. Chem. Soc., Perkin. Trans. 1 1972, 860-869. 
SCHEME 1. Synthetic Strategy for the Synthesis of Nominine $17^{a}$

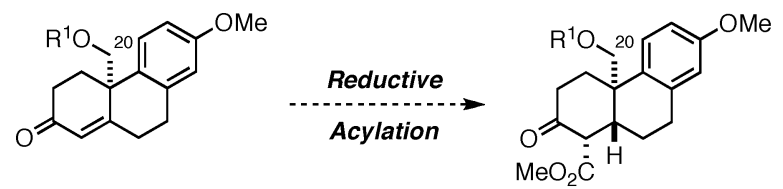

10
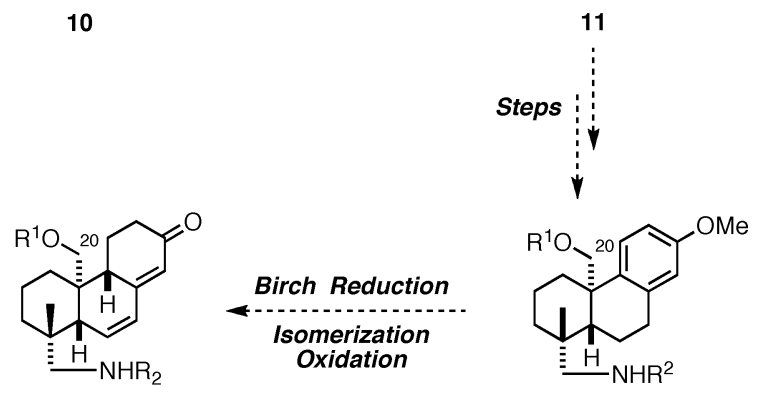

13

Oxidation
Oxization

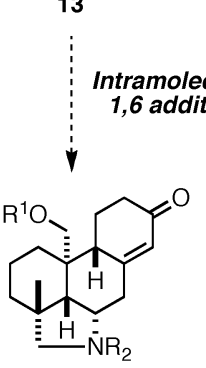

14
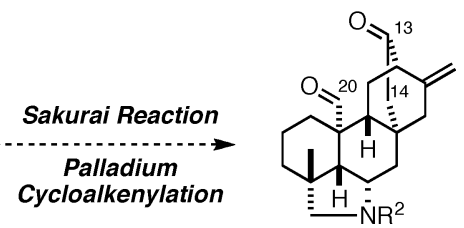

15

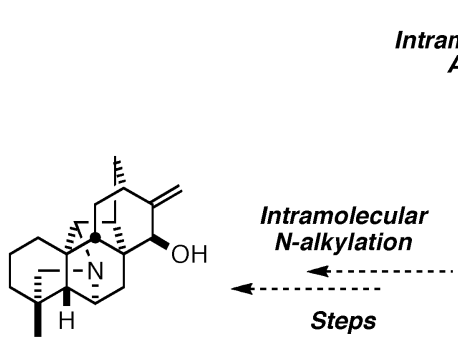

17
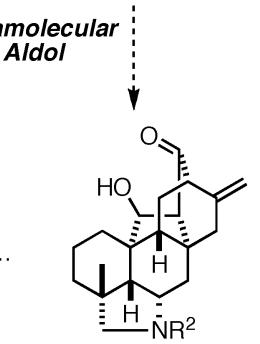

16

${ }^{a}$ Where $\mathrm{R}^{1}$ and $\mathrm{R}^{2}$ are unspecific protecting groups.

yield and the ester function subsequently was reduced with $\mathrm{LiAlH}_{4}$ to give the alcohol 22 in excellent yield. The alcohol function of $\mathbf{2 2}$ was then protected as a MOM ether and the ketal removed on treatment with acid to give the desired enone $\mathbf{2 3}$ in $87 \%$ over the two steps.

With the desired enone in hand the reductive acylation was addressed next. ${ }^{14}$ The dissolving metal reduction of enones in liquid ammonia is a well-established methodology and it has been demonstrated that when the $\beta$-carbon is at the fusion of a decalin-based system, the trans-fused product is the major product. ${ }^{15}$ Accordingly, treatment of the enone $\mathbf{2 3}$ with lithium in liquid ammonia at $-78{ }^{\circ} \mathrm{C}$ followed by a quench with methyl cyanoformate at $-78{ }^{\circ} \mathrm{C}$, followed by warming to $0{ }^{\circ} \mathrm{C}$, affording the desired $\beta$-keto ester 27 in $67 \%$ yield (Scheme 3 ). However, on scale-up we found that we obtained significant amounts of the regioisomer $\mathbf{2 8}$. If, after $5 \mathrm{~min}$, the reaction was quenched at $-78{ }^{\circ} \mathrm{C}$, the desired trans-fused $\beta$-keto ester 27

(14) Mander, L. N.; Sethi, S. P. Tetrahedron Lett. 1983, 24, 5425-5428. Mander, L. N.; Sethi, S. P.; Crabtree, S. R. Org. Synth. 1991, 70, 256.

(15) Keinan, E.; Greenspoon, N. In Comprehensive Organic Synthesis; Trost, B., Ed.; Pergamon Press: Oxford, UK, 1991; Vol. 8.
SCHEME 2. Synthesis of Enone 23<smiles>COC(=O)C1=C(O)CCc2cc(OC)ccc21</smiles>

18

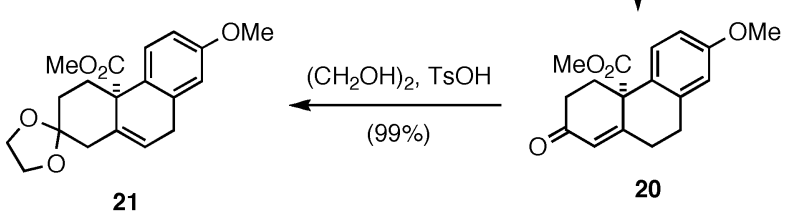

21

19

1. $M V K, \mathrm{Et}_{3} \mathrm{~N}$

2. $\mathrm{pTsOH}, \mathrm{PhH}, 80^{\circ}$ $(67 \%)$

$\mathrm{LiAlH}_{4}$
$(99 \%)$

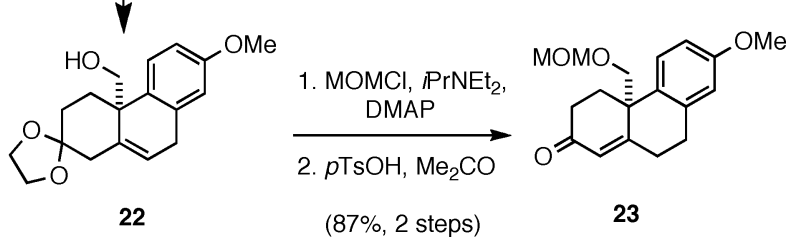

SCHEME 3. Reductive Acylation: Synthesis of $\beta$-Keto Ester 27

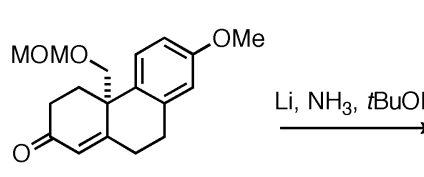

23

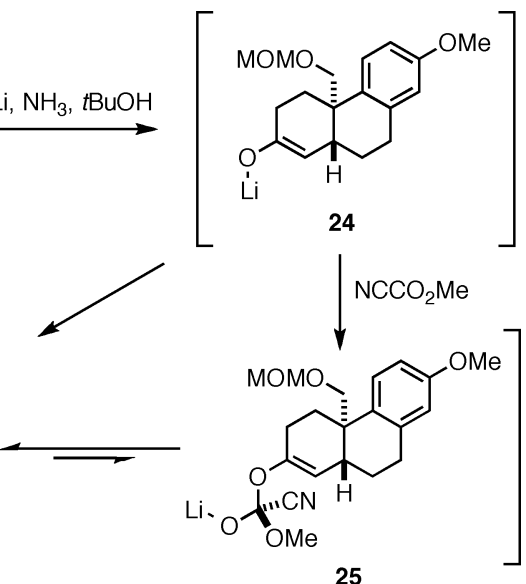
(67\%)<smiles>COC[C@@H]1C(=O)CC[C@]2(COC)c3ccc(OC)cc3CC[C@H]12</smiles>

27<smiles>COC[C@]12CC(O)=C(C(=O)O)C[C@H]1CCc1cc(OC)ccc12</smiles>

28

was isolated in $67 \%$ yield. When, instead, the reaction was allowed to warm to room temperature before quenching, regioisomer $\mathbf{2 8}$ was formed reducing the yield of $\mathbf{2 7}$. We have attributed the success of methyl cyanoformate in the chemoselective $C$-acylation of enolates to the increased stability of the $C$-complex 26, over that of the $O$-complex 25, as a consequence of chelation with the adjacent ketone function. The formation of the regioisomer $\mathbf{2 8}$ leads us to speculate that at higher temperatures the $O$-complex $\mathbf{2 5}$ is in equilibrium with enolate $\mathbf{2 4}$ while the $C$-complex $\mathbf{2 6}$ disassociates to afford the 
SCHEME 4. Attempted Synthesis of Amine 35

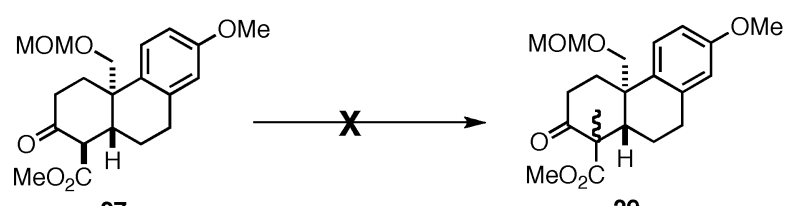

27

29

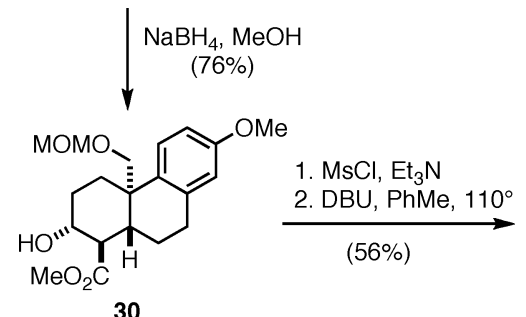

30

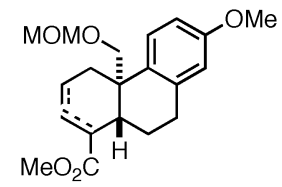

31

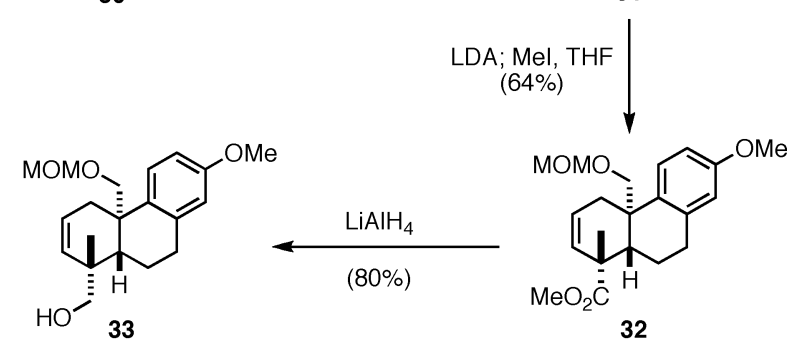

DMP, pyridine
$(85 \%)$

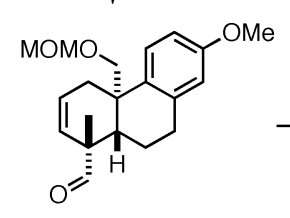

34

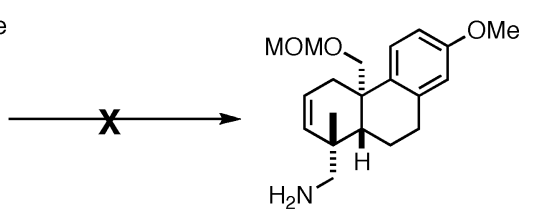

35 $\beta$-keto ester 27, which undergoes enolization, thereby affording a proton source that allows equilibrium between $\mathbf{2 4}$ and its $\Delta^{2}$ isomer.

The next phase of the synthesis is outlined in Scheme 4. With the $\beta$-keto ester 27 in hand, alkylation at C-4 was attempted. Wenkert ${ }^{16}$ et al. had found with a similar substrate possessing a simple angular methyl group at C-10 that alkylation syn to the C-10 methy was slightly favored (2.4:1) due to stereoelectronic factors, ${ }^{17} \mathrm{We}$ reasoned that the increased steric bulk of the MOM substituted methyl would result in a significantly increased yield of product resulting from the methyl group being directed to the upper face of the A-ring, i.e., anti to the angular substituent. In the event, all attempts to alkylate the $\beta$-keto ester 27 under standard conditions $\left(\mathrm{KO}^{t} \mathrm{Bu} / \mathrm{HO}^{t} \mathrm{Bu} / \mathrm{MeI}\right.$ and $\mathrm{NaH} /$ THF/MeI) gave no useful outcomes. ${ }^{17}$ Our attention then turned to modifying the A-ring functionality with the goal of utilizing a more reactive enolate. Accordingly, ketone 27 was treated with $\mathrm{NaBH}_{4}$ in $\mathrm{MeOH}$ to give the $3 \alpha$-hydroxy product 30, which was then converted to the mesylate and eliminated to give the alkene $\mathbf{3 1}$ as a 3:1 mixture of regioisomers in 56\% yield over two steps. Alkylation of this mixture was then effected, delivering the methyl group to the $\beta$-face to give 32 in $64 \%$ yield on treatment with LDA then Mel in THF. The stereo-

(16) Wenkert, E.; Afonso, A.; Bredenberg, J. B.; Kaneko, C.; Tahara, A. J. Am. Chem. Soc. 1964, 86, 2038.

(17) Caine, D. In Comprehensive Organic Synthesis; Trost, B., Ed.; Pergamon Press: Oxford, UK, 1991; Vol. 3, p 1.

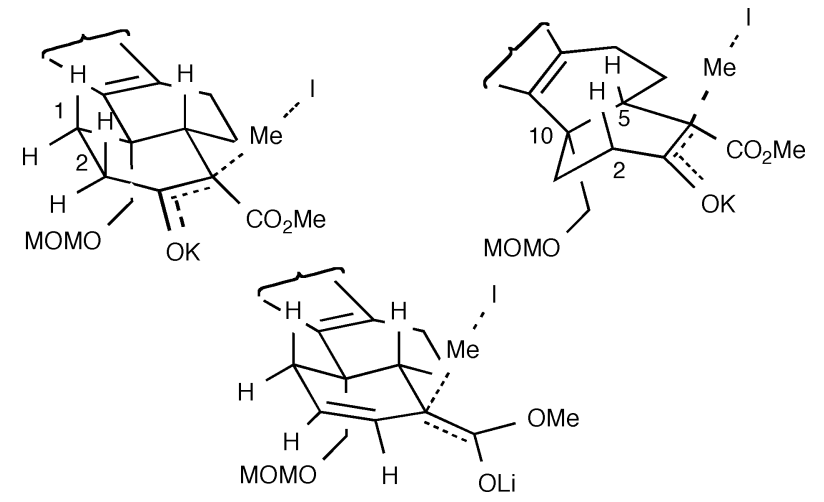

FIGURE 2. Transition states for the alkylation of $\mathbf{2 7}$ and $\mathbf{3 1 .}$

chemistry was assigned on the basis of NOE difference experiments. Thus, irradiation of the methyl resonance at 1.39 ppm showed through-space interactions with the $\mathrm{H} 3$ methine resonance at $5.74 \mathrm{ppm}$, the $\mathrm{H} 6$ methylene at $2.20 \mathrm{ppm}$, and the H5 methine at $1.80 \mathrm{ppm}$. No through-space interaction was seen with the MOM protected angular hydroxymethyl, which would be expected if the methyl resided on the $\alpha$-face.

The failure of the $\beta$-keto ester 27 to undergo alkylation is puzzling. However, the lower face of the A-ring is seriously hindered while for alkylation to take place on the upper face, the A-ring must adopt one of two possible boat-like conformations (Figure 2) so that alkylation can occur along an axial-like vector. Assuming product-like transition states, in one of these conformations $\mathrm{C}-1$ and $\mathrm{C}-2$ are eclipsed and in the other there is a prow interaction between $\mathrm{H}-2 \beta$ and $\mathrm{H}-5 \beta$. In the case of 31, however, the incorporation of the $\Delta^{2}$ bond removes both of these interactions.

The formation of $\mathbf{3 2}$ represents a very satisfactory tactic to overcome the stereoelectronic demands imposed by cyclic $\beta$-keto esters in general and in the present case lends itself to the hydroxylation at $\mathrm{C}-2$ that is a commonly functionalized location in the hetisane alkaloids. Although the ester could be converted to the aldehyde $\mathbf{3 4}$ in an acceptable yield, the development work hinted at side reactions involving the angular MOM protected alcohol function. For example, if the DessMartin periodane oxidation of alcohol $\mathbf{3 3}$ was not buffered with pyridine then the yield was severely reduced. Reductive amination ${ }^{18}$ of aldehyde $\mathbf{3 4}$ was similarly unsuccessful returning either starting material or significant decomposition to large numbers of products. These factors led us to reconsider the appropriateness of the angular MOM protecting group especially considering the complications that could also potentially arise from the upcoming Birch reduction and subsequent acidcatalyzed isomerization (Scheme 1). As well, we still needed to solve the problem of introducing an aminomethyl function at C-4. Accordingly, the alcohol 22 was protected as the TBS ether, and to simplify the task of elaborating the A-ring functionality, we applied the Coates protocol $^{19}$ for removing the C-3 carbonyl group.

Successful Synthesis of Carbonate 42. As outlined above, the alcohol 22 was protected as the TBS ether by using standard conditions and the ketal function removed to yield the enone 36 in $49 \%$ yield over two steps. By using the conditions developed earlier, the enone was smoothly converted to the

(18) Baxter, E. W.; Reitz, A. B. In Organic Reactions; Overman, L., Ed.; John Wiley \& Sons: New York, 2002; Vol. 59.

(19) Coates, R. M.; Shaw, J. E. J. Org. Chem. 1970, 35, 2597. 
SCHEME 5. Synthesis of Carbamate 42
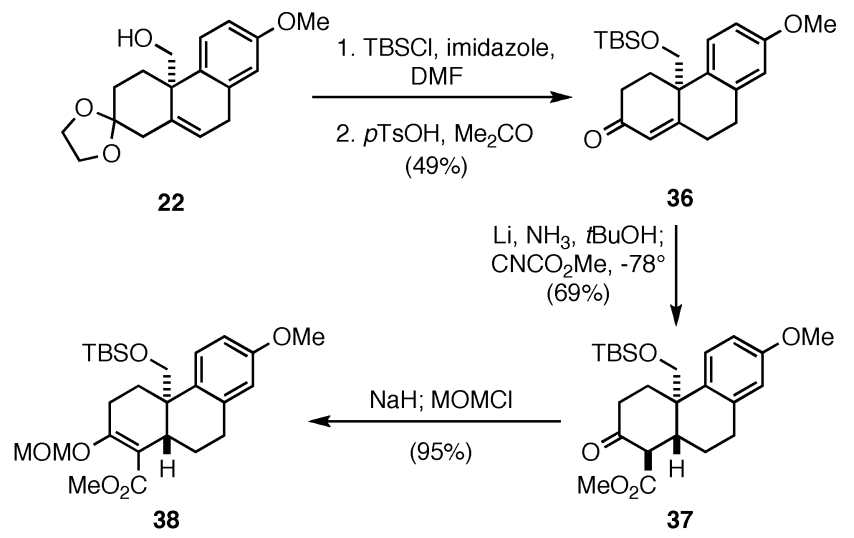

$\mid \begin{gathered}\mathrm{Li}, \mathrm{NH}_{3}, \mathrm{tBuOH} ; \\ (69 \%)\end{gathered}$

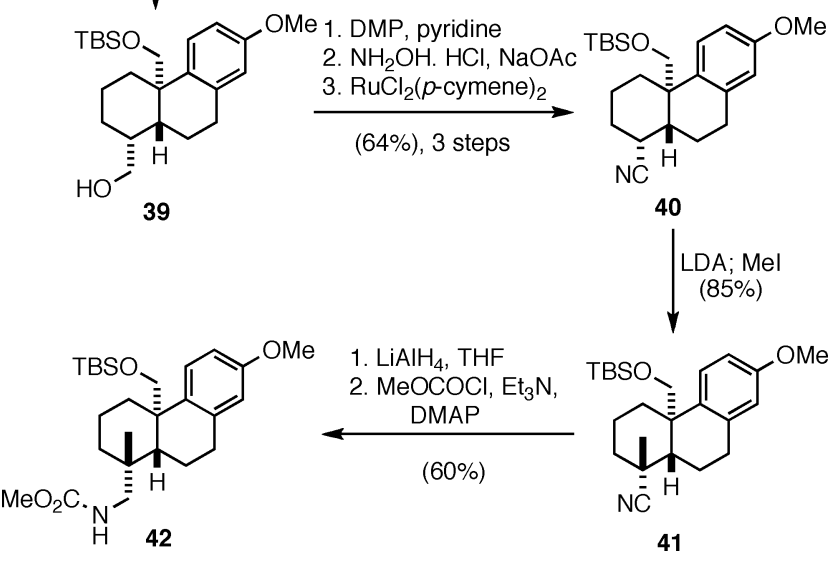

$\beta$-keto ester 37 in $69 \%$ yield. At this point our approach diverged as outlined in Scheme 5, the main difference being the planned use of a C-4 nitrile function for alkylation and introduction of nitrogen. Thus, following the Coates procedure, ${ }^{19} \beta$-keto ester 37 was treated with $\mathrm{NaH}$ and MeI in HMPA to give the enol ether $\mathbf{3 8}$ (95\% yield), reduction of which with lithium in liquid ammonia in the presence of ${ }^{t} \mathrm{BuOH}$ (6 equiv) delivered the alcohol 39 in $69 \%$ yield. Although it was difficult to assign the stereochemistry of the hydroxymethyl group, further experimentation, vide infra, showed this substituent to be $4 \alpha$. This stereochemistry presumably arises due to the kinetic quench of the intermediate ester enolate along the less encumbered equatorial vector.

Alcohol 39 was converted into the nitrile $\mathbf{4 0}$ in three steps: (1) oxidation of the alcohol 39 with DMP/pyridine to the aldehyde; (2) conversion of the aldehyde to the oxime; and (3) dehydration of the oxime to give nitrile $\mathbf{4 0}$ in $64 \%$ yield over three steps. The dehydration step was carried out with catalytic $\mathrm{RuCl}_{2}[p \text {-cymene }]_{2}(2 \%)$ and is a vast improvement over the traditional methods of oxime dehydration, ${ }^{20}$ which typically require forcing conditions at elevated temperatures. Alkylation of the nitrile was achieved under analogous conditions to the ester 31. Treatment of the nitrile $\mathbf{4 0}$ with LDA in THF gave the alkylated product $\mathbf{4 1}$ as a single product in $85 \%$ yield. The higher yield observed for the alkylation of the nitrile compared to the ester $\mathbf{3 1}$ is perhaps a reflection of the fact that the energy penalty associated with a nitrile group occupying the more

(20) Yang, S. H.; Chang, S. C. Org. Lett. 2001, 3, 4209-4211.
SCHEME 6. Synthesis of Pyrrolidine 46
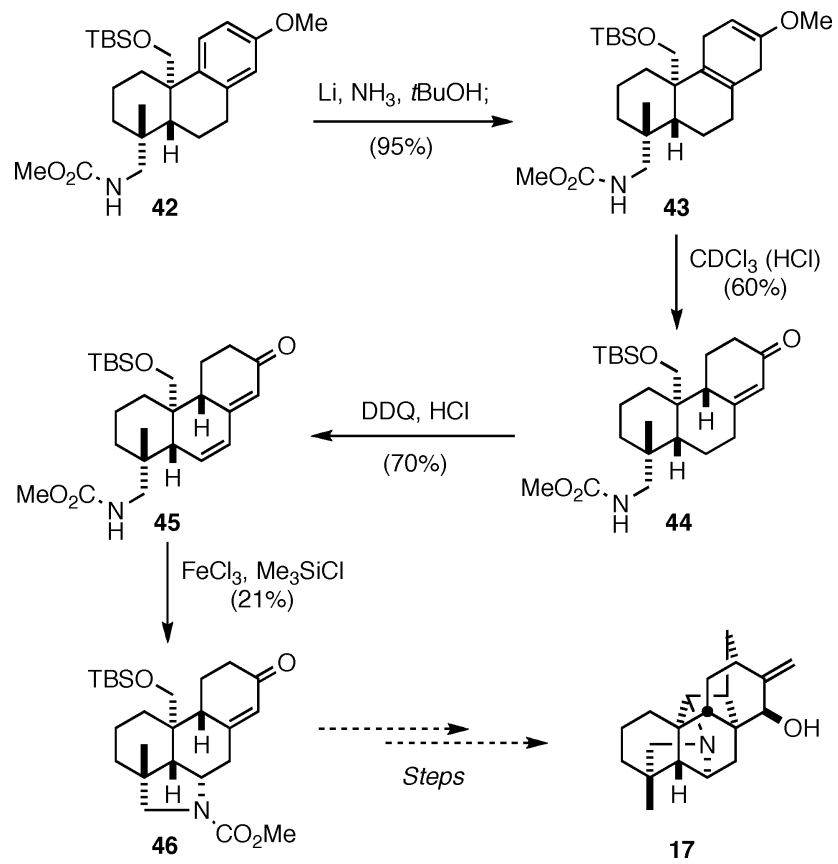

congested $\alpha$-face in the transition state (steric compression) is smaller than that for an ester function, as noted by Fleming. ${ }^{21}$ Finally, with nitrogen efficiently installed into the molecule, our attention turned to the reduction of the nitrile function to an amine and subsequent reduction of the aromatic ring. Thus, reduction of the nitrile function of $\mathbf{4 1}$ with $\mathrm{LiAlH}_{4}$ in THF at reflux gave the amine, which was immediately treated with methyl chloroformate to give the methyl carbonate $\mathbf{4 2}$ in $65 \%$ yield over the two steps. The stereochemistry of the alkylation could now be confirmed with NOE difference experiments showing through-space interactions between the amino methyl protons (3.14 and $3.53 \mathrm{ppm}$ ) and the adjacent TBS protected hydroxy methyl (3.81 ppm). Through comparisons with the ${ }^{1} \mathrm{H}$ NMR spectra of $\mathbf{4 0}$ and $\mathbf{4 1}$, we subsequently assigned the stereochemistry of alcohol $\mathbf{3 9}$.

Synthesis of Pyrrolidine 46. With the requisite AB-ring functionality in place, we addressed the reduction of the anisole ring and then formation of the pyrrolidine ring by means of the planned intramolecular 1,6-addition in dienone $\mathbf{4 5}$ (Scheme 6). Thus, treatment of the carbamate $\mathbf{4 2}$ with lithium in ammonia and ethanol at reflux gave the 1,4-dihydroanisole 43 , which was immediately hydrolyzed to $\alpha, \beta$-enone 44 on treatment with deuterated chloroform, presumably due to trace $\mathrm{HCl}$ and water. This method consistently gave more superior results than the traditional methods $\left(\mathrm{HCl} / \mathrm{CHCl}_{3}, \mathrm{HCl} / \mathrm{Et}_{2} \mathrm{O}\right)$. We also reason that the carbamate function is deprotonated by lithium amide under the Birch conditions rendering it resistant to reduction, an outcome that we anticipated after executing a similar sequence in the preparation of the skeleton of the alkaloid, himandrine. ${ }^{22}$

With the enone $\mathbf{4 4}$ in hand, our attention turned to the formation of the required dienone $\mathbf{4 5}$. Our earlier attempts to effect this transformation via the work of Fuchs were unsuccessful, ${ }^{23}$ but DDQ oxidation under acidic conditions proved

(21) Fleming, F. F.; Zhang, Z. Y. Tetrahedron 2005, 61, 747-789.

(22) O'Connor, P. D.; Mander, L. N.; McLachlan, M. M. W. Org. Lett. 2004, 6, 703-706. 
to be an excellent altenative. ${ }^{24}$ The oxidation was carried out by treating the enone 44 , in benzene with a drop of concentrated $\mathrm{HCl}$, with DDQ delivering the desired dienone $\mathbf{4 5}$ in $\mathbf{7 0 \%}$ yield. The dienone was characterized based on the ${ }^{1} \mathrm{H}$ NMR spectrum, which showed a pair of doublets at 6.32 and $6.21 \mathrm{ppm}$, both with a vicinal coupling of $9.6 \mathrm{~Hz}$, assigned to the two $\gamma$ and $\epsilon$ protons. The ${ }^{13} \mathrm{C}$ NMR spectrum confirmed this finding with the appearance of two resonances at 111.7 and $129.7 \mathrm{ppm}$ for C-7 and C-6, respectively.

Having achieved the synthesis of the dienone 45, our attention was turned to cyclizing the carbamate function on to C-6 of the dienone functionality. Under basic conditions it was considered that the reverse reaction, elimination of a carbamate group, would be facile and therefore it would be best to carry out the cyclization under acidic conditions. Indeed, treatment of the carbamate $\mathbf{4 5}$ with DBU at room temperature or at reflux returned only starting material. Treatment under acidic conditions, employing $p$-TsOH, resulted in decomposition to a number of unidentified products, presumably as a consequence of cleavage of the silyl ether. In light of this outcome, the conditions needed to be sufficiently mild so as to prevent any unwanted side reactions.

A recent paper described the intermolecular 1,4-addition of carbamates to enones catalyzed by $\mathrm{FeCl}_{3}$ and TMS-Cl. ${ }^{25} \mathrm{We}$ reasoned that an intramolecular process would be more favorable and so the carbamate $\mathbf{4 5}$ was treated with $\mathrm{FeCl}_{3}$. After $2 \mathrm{~h}$ no reaction had occurred, but on the addition of 1 equiv of TMS$\mathrm{Cl}$ a rapid reaction took place to yield the desired 1,6-addition product 46 in an unoptimized $21 \%$ yield. The ${ }^{1} \mathrm{H}$ NMR spectrum of 46 indicated that the carbamate existed as a pair of rotamers. Upon heating a sample of 46 to $100{ }^{\circ} \mathrm{C}$ (DMSO- $d_{6}$ ) the rotamers coalesced to a single compound with an indicative amino methine proton at $4.09 \mathrm{ppm}$. From COSY analysis this resonance could be correlated with the two allylic protons, at $2.75(J=$ $6.3 \mathrm{~Hz}, J=19.5 \mathrm{~Hz})$ and $3.12 \mathrm{ppm}(J=8.8 \mathrm{~Hz})$, and the decalin bridgehead proton $1.68 \mathrm{ppm}(J=8.3 \mathrm{~Hz})$.

\section{Conclusion}

We have synthesized a key intermediate that could prove valuable for the total synthesis of the diterpene alkaloid nominine. The synthesis revealed unexpected features of the acylating agent methyl cyanoformate and a new tactic for overcoming the stereoelectronic bias of $\beta$-keto esters. Most importantly this report demonstrates the feasibility of the intramolecular 1,6-addition strategy. The generality of the intramolecular conjugate addition has yet to be realized and provides a new area of Lewis acid catalysis worth exploring. Our future efforts will be directed toward streamlining the synthesis of the dienone $\mathbf{4 5}$ and completing the synthesis of nominine 17.

\section{Experimental Section}

Enone 20. The $\beta$-keto ester 19 (12.2 g, $52 \mathrm{mmol}$ ) was taken up in $\mathrm{MeOH}(100 \mathrm{~mL})$ in a $250-\mathrm{mL}$ round-bottomed flask. The flask was flushed with $\mathrm{N}_{2}$ then triethylamine (17 mmol, $2.4 \mathrm{~mL}$ ) and ethyl vinyl ketone (104 mmol, $8.8 \mathrm{~mL}$ ) were added. After stirring at $\mathrm{rt}$ for $72 \mathrm{~h}$ TLC indicated that the starting material had been

(23) Toth, J. E.; Fuchs, P. L. J. Org. Chem. 1986, 51, 2594-2596. Toth, J. E.; Hamann, P. R.; Fuchs, P. L. J. Org. Chem. 1988, 53, 4694-4708. (24) Walker, D.; Hiebert, J. D. Chem. Rev. 1967, 67, 153-195. (25) Xu, L. W.; Xia, C. G.; Hu, X. X. Chem. Commun. 2003, 25702571 . consumed. The reaction mixture was diluted with EtOAc $(500 \mathrm{~mL})$ and was washed successively with $10 \%$ phosphoric acid $(500 \mathrm{~mL})$, sat. $\mathrm{NaHCO}_{3}(500 \mathrm{~mL})$, and brine $(500 \mathrm{~mL})$. The aqueous layers were re-extracted with EtOAc $(2 \times 500 \mathrm{~mL})$, the combined organic layers were dried over $\mathrm{MgSO}_{4}$ and filtered, and the solvent was removed under reduced pressure. The brown residue was immediately taken up in benzene $(140 \mathrm{~mL})$ in a $250-\mathrm{mL}$ roundbottomed flask and $p$-TsOH $(1 \mathrm{~g})$ added. The flask was then fitted with a Dean-Stark apparatus and condenser, flushed with $\mathrm{N}_{2}$, and heated to reflux for $18 \mathrm{~h}$. The reaction was allowed to cool and most of the toluene was removed under reduced pressure. The reaction mixture was diluted with EtOAc $(200 \mathrm{~mL})$ and washed successively with sat. $\mathrm{NaHCO}_{3}(200 \mathrm{~mL})$ and brine $(200 \mathrm{~mL})$. The aqueous layers were re-extracted with EtOAc $(2 \times 200 \mathrm{~mL})$, the combined organic layers were dried over $\mathrm{MgSO}_{4}$ and filtered, and the solvent was removed under reduced pressure. The brown residue was chromatographed on silica gel (Pet. Sp:EtOAc 4:1) to yield enone 20 (10.2 g, 67\%), which gave yellow crystals from $\mathrm{MeOH}$. $R_{f}: 0.42$ (EA: Pet. Sp. 1:1); mp 81-83 ${ }^{\circ} \mathrm{C}$; MA found C $71.0, \mathrm{H}$ 6.4, $\mathrm{C}_{17} \mathrm{H}_{18} \mathrm{O}_{4}$ requires $\mathrm{C}$ 71.3, $\mathrm{H}$ 6.3; HRMS found $\left(\mathrm{M}^{+}\right)$286.1205, $\mathrm{C}_{17} \mathrm{H}_{18} \mathrm{O}_{4}$ requires 286.1205; IR (film) $v_{\max } 2952,1727,1671,1609$, $1501,1247,1040 \mathrm{~cm}^{-1} ;{ }^{1} \mathrm{H}$ NMR $\left(300 \mathrm{MHz}, \mathrm{CDCl}_{3}\right) \delta 7.37(1 \mathrm{H}$, $\mathrm{d}, J=8.8 \mathrm{~Hz}), 6.78(1 \mathrm{H}, \mathrm{dd}, J=2.8 \mathrm{~Hz}, J=8.8 \mathrm{~Hz}), 6.65(1 \mathrm{H}$, $\mathrm{d}, J=2.8 \mathrm{~Hz}), 6.02(1 \mathrm{H}, \mathrm{s}), 3.79(3 \mathrm{H}, \mathrm{s}), 3.68(3 \mathrm{H}, \mathrm{s}), 2.46-3.14$ $(7 \mathrm{H}, \mathrm{m}), 1.96(1 \mathrm{H}, \mathrm{td}, J=4.7 \mathrm{~Hz}, J=13.9) \cdot{ }^{13} \mathrm{C} \mathrm{NMR}(75 \mathrm{MHz}$, $\left.\mathrm{CDCl}_{3}\right) \delta 198.6(\mathrm{C}), 171.9(\mathrm{C}), 162.5(\mathrm{C}), 158.4(\mathrm{C}), 137.4(\mathrm{C})$, $128.6(\mathrm{C}), 127.9(\mathrm{CH}), 126.2(\mathrm{CH}), 113.4(\mathrm{CH}), 113.2(\mathrm{CH}), 55.2$ $\left(\mathrm{CH}_{3}\right), 52.9\left(\mathrm{CH}_{3}\right), 49.5(\mathrm{C}), 36.0\left(\mathrm{CH}_{2}\right), 35.9\left(\mathrm{CH}_{2}\right), 32.7\left(\mathrm{CH}_{2}\right)$, $30.4\left(\mathrm{CH}_{2}\right)$; MS m/z $286\left(\mathrm{M}^{+}, 27 \%\right), 227,199,171,115$.

Ketal 21. A $50-\mathrm{mL}$ round-bottomed flask was charged with enone 20 ( $1 \mathrm{~g}, 3.5 \mathrm{mmol})$, benzene $(35 \mathrm{~mL})$, ethylene diol (18 mmol, $1 \mathrm{~mL})$, and $p$-TsOH (100 mg). The flask, fitted with a DeanStark apparatus and condenser, was flushed with $\mathrm{N}_{2}$ and heated to reflux for $4 \mathrm{~h}$, after which time TLC indicated that the reaction was complete. The reaction mixture was then allowed to cool and the majority of the benzene removed under reduced pressure. The remainder was diluted with EtOAc $(50 \mathrm{~mL})$ then washed with sat. $\mathrm{NaHCO}_{3}(50 \mathrm{~mL})$ and brine $(50 \mathrm{~mL})$. The aqueous layers were re-extracted with EtOAc $(2 \times 50 \mathrm{~mL})$, the combined organic layers were dried over $\mathrm{MgSO}_{4}$ and filtered, and the solvent was removed under reduced pressure to give the ketal 21 (1.2 g, 99\%) as a yellow oil. A small amount was crystallized from methanol for characterization and the remainder was used without further purification. Mp 111-113 ${ }^{\circ} \mathrm{C} ; R_{f} 0.5$ (Pet. Sp.:EtOAc 1:1); HRMS found $\left(\mathrm{M}^{+}\right)$ 330.1468, $\mathrm{C}_{19} \mathrm{H}_{22} \mathrm{O}_{5}$ requires 330.1467; IR (film) 2952, 1726, 1610, $1503,1241,1117,1042 \mathrm{~cm}^{-1} ;{ }^{1} \mathrm{H}$ NMR $\left(300 \mathrm{MHz}, \mathrm{CDCl}_{3}\right) \delta 7.31$ $(1 \mathrm{H}, \mathrm{d}, J=8.8 \mathrm{~Hz}), 6.72(1 \mathrm{H}, \mathrm{dd}, J=2.8 \mathrm{~Hz}, J=8.7 \mathrm{~Hz}), 6.62$ $(1 \mathrm{H}, \mathrm{d}, J=2.6 \mathrm{~Hz}), 5.82(1 \mathrm{H}, \mathrm{br} \mathrm{s}, \mathrm{H} 10), 3.90(4 \mathrm{H}, \mathrm{m}), 3.77(3 \mathrm{H}$, s), $3.61(3 \mathrm{H}, \mathrm{s}), 3.48(2 \mathrm{H}$, br s), $2.75(1 \mathrm{H}, \mathrm{ddd}, J=13 \mathrm{~Hz}, J=4.1$ $\mathrm{Hz}, J=2.6 \mathrm{~Hz}), 2.40(2 \mathrm{H}$, br s $), 1.90(1 \mathrm{H}, \mathrm{td}, J=13.7 \mathrm{~Hz}, J=$ $4 \mathrm{~Hz}), 1.80(1 \mathrm{H}$, br d, $J=13.9 \mathrm{~Hz}), 1.62(1 \mathrm{H}, \mathrm{td}, J=3.9 \mathrm{~Hz}, 13.7$ $\mathrm{Hz}) ;{ }^{13} \mathrm{C}$ NMR $\left(75 \mathrm{MHz}, \mathrm{CDCl}_{3}\right) \delta 173.8(\mathrm{C}), 158.1(\mathrm{C}), 133.8$ $(\mathrm{C}), 132.3(\mathrm{C}), 127.8(\mathrm{C}), 127.4(\mathrm{CH}), 121.4(\mathrm{CH}), 112.7(\mathrm{CH})$, $112.5(\mathrm{CH}), 108.0(\mathrm{C}), 64.4\left(\mathrm{CH}_{2}\right), 64.3\left(\mathrm{CH}_{2}\right), 55.0\left(\mathrm{CH}_{3}\right), 52.4$ $\left(\mathrm{CH}_{3}\right), 49.6(\mathrm{C}), 43.5\left(\mathrm{CH}_{2}\right), 35.2\left(\mathrm{CH}_{2}\right), 33.0\left(\mathrm{CH}_{2}\right), 30.0\left(\mathrm{CH}_{2}\right)$; MS m/z $330\left(\mathrm{M}^{+}, 44 \%\right), 271,227,209,171,99$.

Alcohol 22. A 50-mL round-bottomed flask was charged with ketal $21(1.2 \mathrm{~g}, 3.5 \mathrm{mmol})$ and dry THF $(14 \mathrm{~mL})$ then cooled to 0 ${ }^{\circ} \mathrm{C}\left(\mathrm{H}_{2} \mathrm{O}\right.$, ice). Freshly ground $\mathrm{LiAlH}_{4}(3.5 \mathrm{mmol}, 132 \mathrm{mg})$ was then slowly added. Once addition was complete the ice bath was removed and the mixture allowed to stir for $2 \mathrm{~h}$. After this time TLC indicated the reaction to be complete. The mixture was filtered through celite and the residue washed with $\mathrm{Et}_{2} \mathrm{O}(2 \times 20 \mathrm{~mL})$. $\mathrm{H}_{2} \mathrm{O}(10 \mathrm{~mL})$ was then slowly added and the organic layer was washed with sat. $\mathrm{NaHCO}_{3}(30 \mathrm{~mL})$ and brine $(30 \mathrm{~mL})$. The aqueous layers were re-extracted with EtOAc $(2 \times 50 \mathrm{~mL})$, the combined organic layers were dried over $\mathrm{MgSO}_{4}$ and filtered, and the solvent was removed under reduced pressure to afford the alcohol $22(1.05$ g, 99\%) as a yellow oil. HRMS found $\left(\mathrm{M}^{+}\right) 302.1519, \mathrm{C}_{18} \mathrm{H}_{22} \mathrm{O}_{4}$ 
requires 302.1518; IR (film) 3468, 2944, 1610, 1502, 1241, 1117, $1088,1048 \mathrm{~cm}^{-1}$; ${ }^{1} \mathrm{H}$ NMR $\left(300 \mathrm{MHz}, \mathrm{CDCl}_{3}\right) \delta 7.17(1 \mathrm{H}, \mathrm{d}, J=$ $8.6 \mathrm{~Hz}), 6.70(1 \mathrm{H}, \mathrm{dd}, J=2.9 \mathrm{~Hz}, J=8.8 \mathrm{~Hz}), 6.58(1 \mathrm{H}, \mathrm{d}, J=$ $2.8 \mathrm{~Hz}), 5.83(1 \mathrm{H}$, br s), $3.80(5 \mathrm{H}, \mathrm{m}), 3.74(3 \mathrm{H}, \mathrm{s}), 3.57(1 \mathrm{H}, \mathrm{d}$, $J=10.9 \mathrm{~Hz}, \mathrm{H} 11), 3.36(2 \mathrm{H}, \mathrm{m}), 2.59(1 \mathrm{H}, \mathrm{m}), 2.23-2.37(2 \mathrm{H}$, $\mathrm{m}), 1.70-1.91(3 \mathrm{H}, \mathrm{m}) ;{ }^{13} \mathrm{C} \mathrm{NMR}\left(75 \mathrm{MHz}, \mathrm{CDCl}_{3}\right) \delta 157.4(\mathrm{C})$, 135.7 (C), 133.7 (C), $131.30(\mathrm{C}), 126.6(\mathrm{CH}), 123.3(\mathrm{CH}), 112.7$ $(\mathrm{CH}), 112.1(\mathrm{CH}), 108.2(\mathrm{C}), 67.1\left(\mathrm{CH}_{2}\right), 64.3\left(\mathrm{CH}_{2}\right), 64.2\left(\mathrm{CH}_{2}\right)$, $54.9\left(\mathrm{CH}_{3}\right), 43.1,41.6\left(\mathrm{C}, \mathrm{CH}_{2}\right), 32.3\left(\mathrm{CH}_{2}\right), 31.6\left(\mathrm{CH}_{2}\right), 30.4$ $\left(\mathrm{CH}_{2}\right)$; MS m/z, $302\left(\mathrm{M}^{+}, 21 \%\right), 271,209,171,128,99$.

MOM Enone 23. A 50-mL round-bottomed flask was charged with ketal $22(1 \mathrm{~g}, 3.6 \mathrm{mmol})$ and dry DCM $(35 \mathrm{~mL})$. The flask was then flushed with $\mathrm{N}_{2}$ and the reaction cooled to $0{ }^{\circ} \mathrm{C}\left(\mathrm{H}_{2} \mathrm{O}\right.$, ice). Diisopropylethylamine ( $35 \mathrm{mmol}, 6.1 \mathrm{~mL})$ was added followed by the slow addition of MOM-Cl $(35 \mathrm{mmol}, 2.7 \mathrm{~mL})$. Once addition was complete, DMAP $(50 \mathrm{mg})$ was added, the ice bath was removed, and the reaction was allowed to stir for $18 \mathrm{~h}$. The reaction was then washed with $10 \%$ phosphoric acid, sat. $\mathrm{NaHCO}_{3}$, and brine. The aqueous layers were re-extracted with EtOAc $(2 \times 20$ $\mathrm{mL}$ ), the combined organic layers were dried over $\mathrm{MgSO}_{4}$ and filtered, and the solvent was removed under reduced pressure to give MOM protected ketal 22a $(1.3 \mathrm{~g},>95 \%)$ as a brown oil. A small portion was chromatographed (Pet. Sp:EtOAc 4:1) for characterization and the remainder used without further purification. Mp 73-75 ${ }^{\circ} \mathrm{C}$; HRMS found $\left(\mathrm{M}^{+}\right) 346.1780, \mathrm{C}_{20} \mathrm{H}_{26} \mathrm{O}_{5}$ requires 346.1780; IR (film) 2946, 2883, 1611, 150, 1243, $1110 \mathrm{~cm}^{-1} ;{ }^{1} \mathrm{H}$ NMR $\left(300 \mathrm{MHz}, \mathrm{CDCl}_{3}\right) \delta 7.26(1 \mathrm{H}, \mathrm{d}, J=8.8 \mathrm{~Hz}), 6.72(1 \mathrm{H}$, $\mathrm{dd}, J=2.8 \mathrm{~Hz}, J=8.6 \mathrm{~Hz}), 6.52(1 \mathrm{H}, \mathrm{d}, J=2.8 \mathrm{~Hz}), 5.81(1 \mathrm{H}$, $\mathrm{m}), 4.37(2 \mathrm{H}, \mathrm{AB}, J=6.6 \mathrm{~Hz}), 3.88-4.00(4 \mathrm{H}, \mathrm{m}), 3.79(1 \mathrm{H}, \mathrm{d}$, $J=9.5 \mathrm{~Hz}), 3.75(3 \mathrm{H}, \mathrm{s}), 3.67(1 \mathrm{H}, \mathrm{d}, J=9.5 \mathrm{~Hz}), 3.31(2 \mathrm{H}, \mathrm{m})$, $3.09(3 \mathrm{H}, \mathrm{s}), 2.69(1 \mathrm{H}, \mathrm{m}), 2.3(2 \mathrm{H}, \mathrm{m}), 1.73-1.94(3 \mathrm{H}, \mathrm{m}) ;{ }^{13} \mathrm{C}$ NMR (75 MHz, $\left.\mathrm{CDCl}_{3}\right) \delta 157.3(\mathrm{C}), 135.3(\mathrm{C}), 134.4(\mathrm{C}), 132.7$ (C), $127.0(\mathrm{CH}), 122.8(\mathrm{CH}), 112.2(\mathrm{CH}), 111.8(\mathrm{CH}), 108.4(\mathrm{C})$, $96.1\left(\mathrm{CH}_{2}\right), 71.8\left(\mathrm{CH}_{2}\right), 64.4\left(\mathrm{CH}_{2}\right), 64.3\left(\mathrm{CH}_{2}\right), 55.0\left(\mathrm{CH}_{3}\right), 54.9$ $\left(\mathrm{CH}_{3}\right), 41.9,41.4\left(\mathrm{C}, \mathrm{CH}_{2}\right), 32.8\left(\mathrm{CH}_{2}\right), 31.8\left(\mathrm{CH}_{2}\right), 30.5\left(\mathrm{CH}_{2}\right)$; MS m/z $346\left(\mathrm{M}^{+}, 46 \%\right), 271,227,209,184,171,99$.

A $50-\mathrm{mL}$ round-bottomed flask was charged with the MOM protected ketal 22a $(1.3 \mathrm{~g}, 3.5 \mathrm{mmol})$ and acetone $(35 \mathrm{~mL})$. $p \mathrm{TsOH}$ (500 mg) was added and the reaction was stirred for $40 \mathrm{~min}$, after which time TLC indicated that the reaction was complete. The majority of the acetone was removed under reduced pressure and the remainder was diluted with EtOAc $(100 \mathrm{~mL})$, then washed with sat. $\mathrm{NaHCO}_{3}(50 \mathrm{~mL})$ and brine $(50 \mathrm{~mL})$. The aqueous layers were then re-extracted with EtOAc $(2 \times 50 \mathrm{~mL})$, the combined organic layers were dried over $\mathrm{MgSO}_{4}$ and filtered, and the solvent was removed under reduced pressure. The residue was then chromatographed (Pet. Sp.:EtOAc 4:1) to yield the MOM protected enone $23(1.1 \mathrm{~g}, 99 \%)$ as a yellow oil. HRMS found $\left(\mathrm{M}^{+}\right) 302.1512$, $\mathrm{C}_{18} \mathrm{H}_{22} \mathrm{O}_{4}$ requires 302.1518; IR (film) 2930, 1669, 1501, 1245, $1149,1107,1040 \mathrm{~cm}^{-1} ;{ }^{1} \mathrm{H}$ NMR $\left(300 \mathrm{MHz}, \mathrm{CDCl}_{3}\right) \delta 7.28(1 \mathrm{H}$, $\mathrm{d}, J=8.8 \mathrm{~Hz}), 6.77(1 \mathrm{H}, \mathrm{dd}, J=2.8 \mathrm{~Hz}, J=8.8 \mathrm{~Hz}), 6.63(1 \mathrm{H}$, $\mathrm{d}, J=2.8 \mathrm{~Hz}), 6.04(1 \mathrm{H}, \mathrm{s}), 4.48(2 \mathrm{H}, \mathrm{AB}, J=6.7 \mathrm{~Hz}), 3.83(2 \mathrm{H}$, $\mathrm{AB}, J=9.7 \mathrm{~Hz}), 3.79(3 \mathrm{H}, \mathrm{s}), 3.22(3 \mathrm{H}, \mathrm{s}), 2.78-3.00(4 \mathrm{H}, \mathrm{m})$, $2.41-2.64(3 \mathrm{H}, \mathrm{m}), 1.99(1 \mathrm{H}, \mathrm{td}, J=14.1 \mathrm{~Hz}, J=5.3 \mathrm{~Hz}) ;{ }^{13} \mathrm{C}$ NMR (75 MHz, $\left.\mathrm{CDCl}_{3}\right) \delta 198.7$ (C), 165.7 (C), 157.5 (C), 136.6 (C), $131.9(\mathrm{C}), 127.4(\mathrm{CH}), 125.9(\mathrm{CH}), 112.7(\mathrm{CH}), 112.6(\mathrm{CH})$, $96.0\left(\mathrm{CH}_{2}\right), 74.5\left(\mathrm{CH}_{2}\right), 55.0\left(\mathrm{CH}_{3}\right), 54.8\left(\mathrm{CH}_{3}\right), 42.4(\mathrm{C}), 34.7$ $\left(\mathrm{CH}_{2}\right), 33.8\left(\mathrm{CH}_{2}\right), 31.4\left(\mathrm{CH}_{2}\right), 30.4\left(\mathrm{CH}_{2}\right) ; \mathrm{MS} \mathrm{m} / \mathrm{z} 302\left(\mathrm{M}^{+}, 6 \%\right)$, 272, 227, 199, 171.

$\beta$-Keto Ester 27. Freshly cleaned lithium wire (17 mmol, 120 $\mathrm{mg}$ ) was added to freshly distilled ammonia $(150 \mathrm{~mL})$ in a 250 $\mathrm{mL}$ three-necked round-bottomed flask at $-78^{\circ} \mathrm{C}$ (acetone/dry ice) under an atmosphere of argon. On dissolution of the lithium (approximately10 $\mathrm{min}$ ), enone $23(500 \mathrm{mg}, 1.7 \mathrm{mmol})$ in dry THF (13 mL) containing ${ }^{t} \mathrm{BuOH}(0.9$ equiv, $1.5 \mathrm{mmol}, 140 \mu \mathrm{L})$ was added quickly, via syringe, to the rapidly stirring dark blue ammonia solution. After the addition was complete the syringe was rinsed with THF $(2 \mathrm{~mL})$ and this was then added to the solution. The dark blue solution was stirred for an additional 2-3 min and then quenched by the addition of isoprene until the dark blue color dissipated. The cold bath was then removed and the ammonia evaporated by gentle heating under a stream of argon. The THF was then pumped under high vacuum to ensure that the ammonia was removed. The flask was recharged with argon and additional THF $(20 \mathrm{~mL})$ added. The solution was then cooled to $-78{ }^{\circ} \mathrm{C}$ (acetone/dry ice) and methyl cyanoformate (1.2 equiv, $2 \mathrm{mmol}$, $160 \mu \mathrm{L}$ ) was added in a dropwise fashion. After $10 \mathrm{~min}$, TLC indicated that the reaction was complete. Cold $\mathrm{H}_{2} \mathrm{O}(5 \mathrm{~mL})$ was added slowly and the solution was stirred for $2 \mathrm{~min}$. Cold diethyl ether $\left(-78{ }^{\circ} \mathrm{C}, 100 \mathrm{~mL}\right)$ was then added followed by the addition of cold $10 \% \mathrm{~K}_{2} \mathrm{CO}_{3}(100 \mathrm{~mL})$. The cold bath was removed and the slurry stirred for $15 \mathrm{~min}$. The ether layer was partitioned and washed successively with $1 \mathrm{M} \mathrm{NaOH}(100 \mathrm{~mL})$ and brine $(100$ $\mathrm{mL}$ ). The aqueous layers were re-extracted with ether and the combined organic layers dried over $\mathrm{MgSO}_{4}$. Removal of the ether under reduced pressure gave an orange oil, which was then chromatographed on silica gel (Pet Sp: EA 4:1) to yield 27 (424 $\mathrm{mg}, 69 \%)$ as a clear oil. HRMS found $\left(\mathrm{M}^{+}\right) 362.1731, \mathrm{C}_{20} \mathrm{H}_{26} \mathrm{O}_{6}$ requires 362.1729; IR (film) 2945, 1744, 1711, 1609, 1500, 1152, $1042 \mathrm{~cm}^{-1} ;{ }^{1} \mathrm{H}$ NMR $\left(300 \mathrm{MHz}, \mathrm{CDCl}_{3}\right) \delta 7.22(1 \mathrm{H}, \mathrm{d}, J=8.7$ $\mathrm{Hz}), 6.67(1 \mathrm{H}, \mathrm{dd}, J=2.6 \mathrm{~Hz}, J=8.5 \mathrm{~Hz}), 6.60(1 \mathrm{H}, \mathrm{d}, J=2.6$ $\mathrm{Hz}), 4.47(2 \mathrm{H}, \mathrm{AB}, J=6.6 \mathrm{~Hz}), 3.92(1 \mathrm{H}, \mathrm{d}, J=10.0 \mathrm{~Hz}, \mathrm{H} 1)$, $3.80(1 \mathrm{H}, \mathrm{d}, J=11 \mathrm{~Hz}), 3.77(3 \mathrm{H}, \mathrm{s}), 3.74(3 \mathrm{H}, \mathrm{s}), 3.59(1 \mathrm{H}, \mathrm{d}, J$ $=10.2 \mathrm{~Hz}), 3.23(3 \mathrm{H}, \mathrm{s}), 2.81-3.05(4 \mathrm{H}, \mathrm{m}), 2.48-2.57(2 \mathrm{H}, \mathrm{m})$, $1.82-1.98(2 \mathrm{H}, \mathrm{m}), 1.61(1 \mathrm{H}, \mathrm{m}) ;{ }^{13} \mathrm{C} \mathrm{NMR}\left(75 \mathrm{MHz}, \mathrm{CDCl}_{3}\right) \delta$ 205.9 (C), 170.4 (C), $158.0(\mathrm{C}), 138.7$ (C), $133.5(\mathrm{C}), 127.2(\mathrm{CH})$, $113.5(\mathrm{CH}), 111.7(\mathrm{CH}), 96.3\left(\mathrm{CH}_{2}\right), 72.1\left(\mathrm{CH}_{2}\right), 60.0(\mathrm{CH}), 55.6$ $\left(\mathrm{CH}_{3}\right), 55.1\left(\mathrm{CH}_{3}\right), 52.1\left(\mathrm{CH}_{3}\right), 43.9(\mathrm{CH}), 38.9,38.3,33.7,29.2$, $23.7\left(4 \times \mathrm{CH}_{2}, \mathrm{C}\right) ; \mathrm{MS} \mathrm{m} / \mathrm{z} 362\left(\mathrm{M}^{+}, 18 \%\right), 287,255,227,199$, 171. After quenching the above reaction at $\mathrm{rt}$ the rearranged product 28 was isolated in $30-60 \%$ yield as a white solid. $\mathrm{Mp} 76-77^{\circ} \mathrm{C}$; HRMS found $\left(\mathrm{M}^{+}\right)$362.1730, $\mathrm{C}_{20} \mathrm{H}_{26} \mathrm{O}_{6}$ requires 362.1729; IR (film) 2930, 1658, 1616, 1501, 1442, $1216 \mathrm{~cm}^{-1} ;{ }^{1} \mathrm{H}$ NMR (300 $\left.\mathrm{MHz}, \mathrm{CDCl}_{3}\right) \delta 12.21(1 \mathrm{H}, \mathrm{s}), 7.34(1 \mathrm{H}, \mathrm{d}, J=8.8 \mathrm{~Hz}), 6.71(1 \mathrm{H}$, $\mathrm{dd}, J=2.8 \mathrm{~Hz}, J=9 \mathrm{~Hz}), 6.61(1 \mathrm{H}, \mathrm{d}, J=2.8 \mathrm{~Hz}), 4.34,4.36$ $(2 \mathrm{H}, \mathrm{AB}, J=6.9 \mathrm{~Hz}), 3.78(3 \mathrm{H}, \mathrm{s}), 3.78(3 \mathrm{H}, \mathrm{s}), 3.57(2 \mathrm{H}, \mathrm{s})$, $3.10(1 \mathrm{H}, \mathrm{d}, J=15.0 \mathrm{~Hz}, \mathrm{H} 4 e), 3.06(3 \mathrm{H}, \mathrm{s}), 2.87(2 \mathrm{H}, \mathrm{s}), 2.25$ $(2 \mathrm{H}, \mathrm{s}), 2.07(1 \mathrm{H}, \mathrm{br} \mathrm{d}, J=15 \mathrm{~Hz}, \mathrm{H} 4 a), 1.96(2 \mathrm{H}, \mathrm{m}), 1.67(1 \mathrm{H}$, $\mathrm{m}) ;{ }^{13} \mathrm{C}$ NMR (75 MHz, $\left.\mathrm{CDCl}_{3}\right) \delta 172.9,170.9(\mathrm{C}), 157.5(\mathrm{C})$, $137.2(\mathrm{C}), 133.7(\mathrm{C}), 128.5(\mathrm{CH}), 112.9(\mathrm{CH}), 111.6(\mathrm{CH}), 96.3$, $96.2\left(\mathrm{CH}_{2}, \mathrm{C}\right), 69.6\left(\mathrm{CH}_{2}\right), 54.9\left(\mathrm{CH}_{3}\right), 54.7\left(\mathrm{CH}_{3}\right), 51.3\left(\mathrm{CH}_{3}\right)$, $38.2(\mathrm{C}), 37.4(\mathrm{CH}), 33.2\left(\mathrm{CH}_{2}\right), 32.0\left(\mathrm{CH}_{2}\right), 29.5\left(\mathrm{CH}_{2}\right), 24.5$ $\left(\mathrm{CH}_{2}\right)$; MS m/z $362\left(\mathrm{M}^{+\bullet}, 25 \%\right), 287,255,227$.

Alcohol 30. A 50-mL round-bottomed flask was charged with the $\beta$-keto ester $27(1.8 \mathrm{~g}, 5 \mathrm{mmol})$ and $\mathrm{MeOH}(50 \mathrm{~mL})$. The flask was flushed with $\mathrm{N}_{2}$ and cooled to $0{ }^{\circ} \mathrm{C}\left(\mathrm{H}_{2} \mathrm{O}\right.$, ice), then $\mathrm{NaBH}_{4}(5$ mmol, $190 \mathrm{mg}$ ) was slowly added. After the addition was complete the ice bath was removed and the reaction was allowed to stir at $\mathrm{rt}$ for $1 \mathrm{~h}$. The majority of the solvent was removed under reduced pressure and the remainder diluted with $\mathrm{Et}_{2} \mathrm{O}(50 \mathrm{~mL}) . \mathrm{H}_{2} \mathrm{O}(10$ $\mathrm{mL})$ was carefully added, followed by $3 \mathrm{M} \mathrm{HCl}(10 \mathrm{~mL})$. After stirring for $5 \mathrm{~min}$ the reaction mixture was washed successively with $\mathrm{H}_{2} \mathrm{O}(50 \mathrm{~mL})$, sat. $\mathrm{NaHCO}_{3}$, and brine. The aqueous layers were re-extracted with EtOAc $(2 \times 50 \mathrm{~mL})$, the combined organic layers were dried over $\mathrm{MgSO}_{4}$ and filtered, and the solvent was removed under reduced pressure to give the crude alcohol $\mathbf{3 0}$ as a white solid $(1.4 \mathrm{~g}, 76 \%)$. A small portion of the residue was chromatographed on silica gel (Pet. Sp.:EtOAc 2:1) and then crystallized from $\mathrm{MeOH}$, the remainder was used without further purification. Mp $128^{\circ} \mathrm{C}$; EA found $\mathrm{C} 65.4, \mathrm{H} \mathrm{7.7,} \mathrm{C}_{20} \mathrm{H}_{28} \mathrm{O}_{6}$ requires C 65.9, H 7.7; HRMS found $\left(\mathrm{M}^{+}\right)$364.1887, $\mathrm{C}_{20} \mathrm{H}_{28} \mathrm{O}_{6}$ requires 364.1886; IR (film) 3267, 2934, 1725, 1610, 1499, 1153, 1051 $\mathrm{cm}^{-1} ;{ }^{1} \mathrm{H} \mathrm{NMR}\left(300 \mathrm{MHz}, \mathrm{CDCl}_{3}\right) \delta 7.22(1 \mathrm{H}, \mathrm{d}, J=8.8 \mathrm{~Hz})$, $6.64(1 \mathrm{H}, \mathrm{dd}, J=2.8 \mathrm{~Hz}, J=8.6 \mathrm{~Hz}), 6.57(1 \mathrm{H}, \mathrm{d}, J=2.8 \mathrm{~Hz})$, $4.36(2 \mathrm{H}, \mathrm{AB}, J=6.6 \mathrm{~Hz}), 3.82(1 \mathrm{H}, \mathrm{dt}, J=4.4 \mathrm{~Hz}, J=10.8$ $\mathrm{Hz}), 3.77(1 \mathrm{H}, \mathrm{d}, J=9.5 \mathrm{~Hz}), 3.74(3 \mathrm{H}, \mathrm{s}), 3.73(3 \mathrm{H}, \mathrm{s}), 3.46(1 \mathrm{H}$, $\mathrm{d}, J=9.5 \mathrm{~Hz}), 3.14(3 \mathrm{H}, \mathrm{s}), 2.86(2 \mathrm{H}, \mathrm{m}), 2.62(2 \mathrm{H}, \mathrm{m}), 1.66(4 \mathrm{H}$, m), 1.34-1.52 (2H, m); $\left.{ }^{13} \mathrm{C} \mathrm{NMR} \mathrm{(300} \mathrm{MHz,} \mathrm{CDCl}_{3}\right) \delta 175.2(\mathrm{C})$, 
$157.5(\mathrm{C}), 136.7,134.8(\mathrm{C}), 127.4(\mathrm{CH}), 113.2(\mathrm{CH}), 111.0(\mathrm{CH})$, $96.4\left(\mathrm{CH}_{2}\right), 72.3(\mathrm{CH}), 69.6\left(\mathrm{CH}_{2}\right), 55.1\left(\mathrm{CH}_{3}\right), 55.0\left(\mathrm{CH}_{3}\right), 53.6$ $(\mathrm{CH}), 51.6\left(\mathrm{CH}_{3}\right), 42.8(\mathrm{CH}), 38.8(\mathrm{C}), 31.2\left(\mathrm{CH}_{2}\right), 30.5\left(\mathrm{CH}_{2}\right)$, $28.9\left(\mathrm{CH}_{2}\right), 22.4\left(\mathrm{CH}_{2}\right)$; MS m/z $364\left(\mathrm{M}^{+}, 26 \%\right), 333,289,271$, 229, $211,171$.

Alkene Ester 31. A 50-mL round-bottomed flask was charged with alcohol 30 (190 mg, $52 \mathrm{mmol})$ and dry DCM $(5 \mathrm{~mL})$, flushed with $\mathrm{N}_{2}$, and cooled to $0{ }^{\circ} \mathrm{C}\left(\mathrm{H}_{2} \mathrm{O}\right.$, ice). Triethylamine $(1.6 \mathrm{mmol}$, $216 \mu \mathrm{L}$ ) was then added followed by the careful addition of $\mathrm{MsCl}$ (1.6 mmol, $120 \mu \mathrm{L}$ ). A crystal of DMAP was added, the ice bath was removed, and the reaction was allowed to stir for $4 \mathrm{~h}$. The reaction was sequentially washed with $\mathrm{H}_{2} \mathrm{O}(5 \mathrm{~mL}), 10 \% \mathrm{HCl}(5$ $\mathrm{mL})$, sat. $\mathrm{NaHCO}_{3}(5 \mathrm{~mL})$, and brine $(5 \mathrm{~mL})$. The aqueous layers were then re-extracted with EtOAc $(2 \times 5 \mathrm{~mL})$, the combined organic layers were dried over $\mathrm{MgSO}_{4}$ and filtered, and the solvent was removed under reduced pressure. The residue was then chromatographed on silica gel (Pet. Sp.:EtOAc 4:1 then 2:1) to yield mesylate 30a $(192 \mathrm{mg}, 83 \%)$ as a yellow oil; $R_{f} 0.23$ (Pet. Sp.:EtOAc 2:1); HRMS found $\left(\mathrm{M}^{+}\right) 442.1664, \mathrm{C}_{21} \mathrm{H}_{30} \mathrm{O}_{8} \mathrm{~S}$ requires 442.1661; IR (film) 2928, 1723, 1614, 1579, 1502, 1358, 1212, $1175 \mathrm{~cm}^{-1} ;{ }^{1} \mathrm{H}$ NMR $\left(300 \mathrm{MHz}, \mathrm{CDCl}_{3}\right) \delta 7.18(1 \mathrm{H}, \mathrm{d}, J=8.6$ $\mathrm{Hz}), 6.64(1 \mathrm{H}, \mathrm{dd}, J=2.8 \mathrm{~Hz}, J=8.6 \mathrm{~Hz}), 6.57(1 \mathrm{H}, \mathrm{d}, J=2.6$ $\mathrm{Hz}), 4.76(1 \mathrm{H}, \mathrm{dt}, J=5.1 \mathrm{~Hz}, J=11.4 \mathrm{~Hz}), 4.39(2 \mathrm{H}, \mathrm{AB}, J=$ $6.6 \mathrm{~Hz}), 3.73(4 \mathrm{H}, \mathrm{br} \mathrm{s}), 3.73(3 \mathrm{H}, \mathrm{s}), 3.44(1 \mathrm{H}, \mathrm{d}, J=9.8 \mathrm{~Hz})$, $3.16(3 \mathrm{H}, \mathrm{s}), 2.96(1 \mathrm{H}, \mathrm{t}, J=11.4 \mathrm{~Hz}), 2.94(3 \mathrm{H}, \mathrm{s}), 2.88(2 \mathrm{H}, \mathrm{m})$, $2.66(1 \mathrm{H}, \mathrm{m}), 2.32(1 \mathrm{H}, \mathrm{m}), 1.81-2.12(3 \mathrm{H}, \mathrm{m}), 1.42-1.52(2 \mathrm{H}$, $\mathrm{m}) ;{ }^{13} \mathrm{C}$ NMR $\left(300 \mathrm{MHz}, \mathrm{CDCl}_{3}\right) \delta 173.8(\mathrm{C}), 157.8(\mathrm{C}), 136.2$ (C), $133.9(\mathrm{C}), 127.3(\mathrm{CH}), 113.3(\mathrm{CH}), 111.3(\mathrm{CH}), 96.3\left(\mathrm{CH}_{2}\right)$, $82.7(\mathrm{CH}), 70.0\left(\mathrm{CH}_{2}\right), 55.2\left(\mathrm{CH}_{3}\right), 54.9\left(\mathrm{CH}_{3}\right), 51.9\left(\mathrm{CH}_{3}\right), 50.5$ $(\mathrm{CH}), 43.2(\mathrm{CH}), 38.5(\mathrm{C}), 37.9\left(\mathrm{CH}_{3}\right), 31.2\left(\mathrm{CH}_{2}\right), 28.6\left(\mathrm{CH}_{2}\right)$, $28.3\left(\mathrm{CH}_{2}\right), 22.1\left(\mathrm{CH}_{2}\right)$; MS m/z $442\left(\mathrm{M}^{+}, 7 \%\right), 367,271,211$, 197, 171. A 25-mL round-bottomed flask was charged with the mesylate 30a (1.3 g, $2.9 \mathrm{mmol})$, toluene $(29 \mathrm{~mL})$, and DBU (21 mmol, $3.1 \mathrm{~mL}$ ). The flask was fitted with a condenser, flushed with $\mathrm{N}_{2}$, heated to reflux, and stirred for 2 days. The reaction was allowed to cool and $\mathrm{Et}_{2} \mathrm{O}(100 \mathrm{~mL})$ was added. The mixture was washed successively with $10 \%$ phosphoric acid $(50 \mathrm{~mL}), \mathrm{H}_{2} \mathrm{O}(50 \mathrm{~mL})$, $\mathrm{NaHCO}_{3}(50 \mathrm{~mL})$, and brine $(50 \mathrm{~mL})$. The aqueous layers were then re-extracted with EtOAc $(2 \times 50 \mathrm{~mL})$, the combined organic layers were dried over $\mathrm{MgSO}_{4}$ and filtered, and the solvent was removed under reduced pressure. The residue was chromatographed on silica gel (Pet. Sp:EtOAc 4:1) to yield the mixture of olefinic esters 31 (670 mg, 67\%) as an inseparable mixture. $R_{f} 0.54$ (Pet. Sp.:EtOAc 2:1); HRMS found $\left(\mathrm{M}^{+}\right) 346.1781, \mathrm{C}_{20} \mathrm{H}_{26} \mathrm{O}_{5}$ requires 346.1780; IR (film) 2928, 1738, 1715, 1609, 1501, 1241, 1152, $1043 \mathrm{~cm}^{-1} ;{ }^{1} \mathrm{H}$ NMR $\left(300 \mathrm{MHz}, \mathrm{CDCl}_{3}\right) \delta 7.31\left({ }^{2} /{ }_{3} \mathrm{H}, \mathrm{d}\right), 7.25$ $\left(1 /{ }_{3} \mathrm{H}, \mathrm{d}, J=8.8 \mathrm{~Hz}\right), 6.80\left({ }_{1} /{ }_{3} \mathrm{H}, \mathrm{m}, \mathrm{H} 3\right), 6.70(2 \mathrm{H}, \mathrm{dd}, J=3.1$ $\mathrm{Hz}, J=8.9 \mathrm{~Hz}), 6.67(1 \mathrm{H}, \mathrm{d}, J=0.3 \mathrm{~Hz}), 6.59(1 \mathrm{H}, \mathrm{d}, J=2.6$ $\mathrm{Hz}), 5.86\left({ }^{2} /{ }_{3} \mathrm{H}, \mathrm{m}\right), 5.64(2 / 3 \mathrm{H}, \mathrm{m}), 4.45(1 \mathrm{H}, \mathrm{d}, J=6.4 \mathrm{~Hz}), 4.40$ $\left(1 /{ }_{3} \mathrm{H}, \mathrm{d}, J=6.4 \mathrm{~Hz}\right), 4.36\left(2 /{ }_{3} \mathrm{H}, \mathrm{d}, J=6.6 \mathrm{~Hz}\right), 4.32\left(2 /{ }_{3} \mathrm{H}, \mathrm{d}, J\right.$ $=6.6 \mathrm{~Hz}), 3.77(3 \mathrm{H}, \mathrm{s}), 3.74(3 \mathrm{H}, \mathrm{s}), 3.66(2 / 3 \mathrm{H}, \mathrm{d}, J=9.2 \mathrm{~Hz})$, $3.61(2 / 3 \mathrm{H}, \mathrm{d}, J=9.4 \mathrm{~Hz}), 3.57(1 / 3 \mathrm{H}, \mathrm{d}, J=9.5 \mathrm{~Hz}), 3.43\left(1 /{ }_{3} \mathrm{H}\right.$, $\mathrm{d}, J=9.1 \mathrm{~Hz}), 3.10(3 \mathrm{H}, \mathrm{s}), 3.08(\mathrm{H}, \mathrm{s}), 2.66-3.05(7 \mathrm{H}, \mathrm{m}), 1.45-$ $2.4(10 \mathrm{H}, \mathrm{m}) ;{ }^{13} \mathrm{C} \mathrm{NMR}\left(75 \mathrm{MHz}, \mathrm{CDCl}_{3}\right) \delta 177.4,168.5(\mathrm{C}), 157.8$ (C), $157.6(\mathrm{C}), 138.5(\mathrm{CH}), 137.3(\mathrm{C}), 137.0(\mathrm{C}), 134.0(\mathrm{C}), 133.2$ (C), $135.5(\mathrm{C}), 128.5(\mathrm{CH}), 128.4(\mathrm{CH}), 126.7(\mathrm{CH}), 124.1(\mathrm{CH})$, $113.8(\mathrm{CH}), 112.9(\mathrm{CH}), 111.7(\mathrm{CH}), 110.6(\mathrm{CH}), 96.6\left(\mathrm{CH}_{2}\right), 96.4$ $\left(\mathrm{CH}_{2}\right), 70.3\left(\mathrm{CH}_{2}\right), 69.0\left(\mathrm{CH}_{2}\right), 55.0\left(\mathrm{CH}_{3}\right), 55.0\left(\mathrm{CH}_{3}\right), 52.0\left(\mathrm{CH}_{3}\right)$, $51.4\left(\mathrm{CH}_{3}\right), 46.0(\mathrm{CH}), 40.6(\mathrm{CH}), 40.1(\mathrm{CH}), 38.7(\mathrm{C}), 38.1(\mathrm{C})$, $34.7\left(\mathrm{CH}_{2}\right), 29.7\left(\mathrm{CH}_{2}\right), 28.3\left(\mathrm{CH}_{2}\right), 27.2\left(\mathrm{CH}_{2}\right), 23.4\left(\mathrm{CH}_{2}\right), 23.2$ $\left(\mathrm{CH}_{2}\right), 20.1\left(\mathrm{CH}_{2}\right) ; \mathrm{MS} \mathrm{m} / z, 346\left(\mathrm{M}^{+}, 30 \%\right), 271,211,196,176$, 165.

Alkylated Ester 32. A 50-mL round-bottomed flask was charged with dry THF $(15 \mathrm{~mL})$ and diisopropylamine $(3.2 \mathrm{mmol}, 451 \mu \mathrm{L})$. The flask was then flushed with $\mathrm{N}_{2}$ and cooled to $0{ }^{\circ} \mathrm{C}\left(\mathrm{H}_{2} \mathrm{O}\right.$, ice). $n$-BuLi [1.6 M in hexanes] (3.2 mmol. $2 \mathrm{~mL})$ was then added in a dropwise fashion. After $15 \mathrm{~min}$ the alkenes ester $\mathbf{3 1}(570 \mathrm{mg}, 1.6$ $\mathrm{mmol})$ in dry THF $(16 \mathrm{~mL})$ was slowly added via syringe. The reaction was stirred at $0{ }^{\circ} \mathrm{C}$ for $30 \mathrm{~min}$ and then iodomethane $(8$ mmol, $500 \mu \mathrm{L}$ ) was added. The ice bath was removed and the reaction was stirred for an additional $2 \mathrm{~h}$. The reaction was then quenched by the careful addition of $\mathrm{H}_{2} \mathrm{O}(2 \mathrm{~mL})$. The reaction was diluted with EtOAc $(20 \mathrm{~mL})$ and then with $\mathrm{H}_{2} \mathrm{O}(2 \times 20 \mathrm{~mL})$ and brine $(20 \mathrm{~mL})$. The aqueous layers were re-extracted with EtOAc $(2 \times 20 \mathrm{~mL})$, the combined organic layers were then dried over $\mathrm{MgSO}_{4}$ and filtered, and the solvent was removed under reduced pressure. The residue was chromatographed (Pet. Sp.:EA 4:1) on silica gel to give the alkylated ester $32(370 \mathrm{mg}, 64 \%)$ as a pale yellow oil. $R_{f} 0.78$ (Pet. Sp.: EtOAc 1:2); HRMS found $\left(\mathrm{M}^{+}\right)$ $360.1940, \mathrm{C}_{21} \mathrm{H}_{28} \mathrm{O}_{5}$ requires 360.1937; IR (film) 2948, 1728, 1609, $1501,1239,1044 \mathrm{~cm}^{-1} ;{ }^{1} \mathrm{H}$ NMR $\left(300 \mathrm{MHz}, \mathrm{CDCl}_{3}\right) \delta 7.25(1 \mathrm{H}$, $\mathrm{d}, J=8.8 \mathrm{~Hz}), 6.69(1 \mathrm{H}, \mathrm{dd}, J=2.8 \mathrm{~Hz}, J=8.6 \mathrm{~Hz}), 6.60(1 \mathrm{H}$, $\mathrm{d}, J=2.8 \mathrm{~Hz}), 5.74(2 \mathrm{H}, \mathrm{m}), 4.30(2 \mathrm{H}, \mathrm{AB}, J=6.3 \mathrm{~Hz}), 3.76$ $(3 \mathrm{H}, \mathrm{s}), 3.69(1 \mathrm{H}, \mathrm{d}, J=9.7 \mathrm{~Hz}), 3.66(3 \mathrm{H}, \mathrm{s}), 3.61(1 \mathrm{H}, \mathrm{d}, J=$ $9.5 \mathrm{~Hz}), 3.00(3 \mathrm{H}, \mathrm{s}), 2.73-2.98(3 \mathrm{H}, \mathrm{m}), 2.11-2.2(2 \mathrm{H}, \mathrm{m}), 1.98$ $(1 \mathrm{H}, \mathrm{d}, J=17.6 \mathrm{~Hz}), 1.82(1 \mathrm{H}, \mathrm{dd}, J=6.7 \mathrm{~Hz}, J=8.2 \mathrm{~Hz}), 1.39$ $(3 \mathrm{H}, \mathrm{s}) ;{ }^{13} \mathrm{C} \mathrm{NMR}\left(75 \mathrm{MHz}, \mathrm{CDCl}_{3}\right) \delta 175.8(\mathrm{C}), 157.4(\mathrm{C}), 137.5$ (C), $135.0(\mathrm{C}), 131.5(\mathrm{CH}), 128.8(\mathrm{CH}), 124.6(\mathrm{CH}), 112.6(\mathrm{CH})$, $111.8(\mathrm{CH}), 96.0\left(\mathrm{CH}_{2}\right), 71.0\left(\mathrm{CH}_{2}\right), 55.0\left(\mathrm{CH}_{3}\right), 54.8\left(\mathrm{CH}_{3}\right), 51.6$ $\left(\mathrm{CH}_{3}\right), 49.6(\mathrm{CH}), 45.6(\mathrm{C}), 39.5(\mathrm{C}), 36.2\left(\mathrm{CH}_{2}\right), 31.6\left(\mathrm{CH}_{2}\right), 21.0$ $\left(\mathrm{CH}_{2}\right), 27.9\left(\mathrm{CH}_{3}\right) ; \mathrm{MS} \mathrm{m} / z 360\left(\mathrm{M}^{+}, 1 \%\right), 285,239,225,210$.

Aldehyde 34. The alkylated ester 32 (145 mg, $0.4 \mathrm{mmol})$ was taken up in dry THF $(4 \mathrm{~mL})$ and cooled to $0{ }^{\circ} \mathrm{C}\left(\mathrm{H}_{2} \mathrm{O} / \mathrm{Ice}\right)$. $\mathrm{LiAlH}_{4}$ ( $1 \mathrm{M}$ soln in THF, $0.4 \mathrm{mmol}, 400 \mu \mathrm{L}$ ) was added slowly and the reaction allowed to warm to $\mathrm{rt}$ over $30 \mathrm{~min}$. The reaction was then cooled and $\mathrm{H}_{2} \mathrm{O}(10 \mathrm{~mL})$ slowly added to quench the excess hydride. The aqueous layer was then extracted with EtOAc $(3 \times 10 \mathrm{~mL})$ and the organic layers washed with $10 \% \mathrm{HCl}(10 \mathrm{~mL}), 1 \mathrm{M} \mathrm{NaOH}$ $(10 \mathrm{~mL})$, and brine $(10 \mathrm{~mL})$. The organic layer was then dried over $\mathrm{MgSO}_{4}$ and filtered, and the solvent was removed under reduced pressure to give the alcohol $\mathbf{3 3}(115 \mathrm{mg}, 80 \%)$ as a white foam. $R_{f}$ 0.5 (Pet. Sp.: EtOAc 1:2); HRMS found $\left(\mathrm{M}^{+}\right) 332.1990, \mathrm{C}_{20} \mathrm{H}_{28} \mathrm{O}_{4}$ requires 332.1988; IR (film) 3341, 2933, 1608, 1500, $1041 \mathrm{~cm}^{-1}$; ${ }^{1} \mathrm{H} \mathrm{NMR}\left(300 \mathrm{MHz}, \mathrm{CDCl}_{3}\right) \delta 7.22(1 \mathrm{H}, \mathrm{d}, J=8.8 \mathrm{~Hz}), 6.70(1 \mathrm{H}$, $\mathrm{dd}, J=2.9 \mathrm{~Hz}, J=8.8 \mathrm{~Hz}), 6.58(1 \mathrm{H}, \mathrm{d}, J=2.8 \mathrm{~Hz}), 5.72(1 \mathrm{H}$, ddd, $J=1.5 \mathrm{~Hz}, J=4.7 \mathrm{~Hz}, J=10.1 \mathrm{~Hz}), 5.65(1 \mathrm{H}, \mathrm{dd}, J=2.5$ $\mathrm{Hz}, J=10.4 \mathrm{~Hz}), 4.31(2 \mathrm{H}, \mathrm{AB}, J=4 \mathrm{~Hz}), 3.86(1 \mathrm{H}, \mathrm{d}, J=9.8$ $\mathrm{Hz}), 3.77(4 \mathrm{H}, \mathrm{s}+\mathrm{d}), 3.53(2 \mathrm{H}, \mathrm{m}), 2.99(3 \mathrm{H}, \mathrm{s}), 2.81-2.98(2 \mathrm{H}$, $\mathrm{m}), 2.61(1 \mathrm{H}, \mathrm{dd}, J=5.9 \mathrm{~Hz}, J=17 \mathrm{~Hz}), 1.85-2.16(4 \mathrm{H}, \mathrm{m})$, $1.21(3 \mathrm{H}, \mathrm{s}) ;{ }^{13} \mathrm{C}$ NMR (75 MHz, $\left.\mathrm{CDCl}_{3}\right) \delta 157.4(\mathrm{C}), 137.7(\mathrm{C})$, $135.5(\mathrm{C}), 133.5(\mathrm{CH}), 128.2(\mathrm{CH}), 124.5(\mathrm{CH}), 112.7(\mathrm{CH}), 111.9$ $(\mathrm{CH}), 96.3\left(\mathrm{CH}_{2}\right), 73.2\left(\mathrm{CH}_{2}\right), 67.5\left(\mathrm{CH}_{2}\right), 55.1\left(\mathrm{CH}_{3}\right), 55.0\left(\mathrm{CH}_{3}\right)$, $48.4(\mathrm{CH}), 40.2(\mathrm{C}), 39.4(\mathrm{C}), 36.4\left(\mathrm{CH}_{2}\right), 31.3\left(\mathrm{CH}_{2}\right), 19.4\left(\mathrm{CH}_{2}\right)$, $26.2\left(\mathrm{CH}_{3}\right) ; \mathrm{MS} m / z 332\left(\mathrm{M}^{+}, 33 \%\right), 257,239,225,211,147$. The alcohol 33 (115 mg, $0.35 \mathrm{mmol}$ ) was dissolved in dry DCM (5 $\mathrm{mL})$, flushed with argon, and cooled to $0{ }^{\circ} \mathrm{C}\left(\mathrm{H}_{2} \mathrm{O}\right.$, ice $)$. Pyridine $(0.38 \mathrm{mmol}, 30 \mu \mathrm{L})$ was then added, followed by DMP $(0.38 \mathrm{mmol}$, $155 \mathrm{mg}$ ). The ice bath was then removed and the solution stirred for $3 \mathrm{~h}$ after which time TLC indicated that all the starting material had been consumed. $\mathrm{H}_{2} \mathrm{O}(1 \mathrm{~mL})$ was then added followed by $1 \mathrm{M}$ $\mathrm{NaOH}(1 \mathrm{~mL})$ and $1 \mathrm{M} \mathrm{Na}_{2} \mathrm{~S}_{2} \mathrm{O}_{5}(1 \mathrm{~mL})$. The white suspension was stirred until all the solids had dissolved ( $\sim 30 \mathrm{~min})$. $\mathrm{NaOH}$ (1 $\mathrm{M}, 10 \mathrm{~mL}$ ) was added and the aqueous layer extracted with EtOAc $(3 \times 10 \mathrm{~mL})$. The organic layers were washed with $10 \%$ phosphoric acid $(10 \mathrm{~mL}), 1 \mathrm{M} \mathrm{NaOH}(10 \mathrm{~mL})$, and brine $(10 \mathrm{~mL})$. The combined organic layers were then dried over $\mathrm{MgSO}_{4}$ and filtered, and the solvent was removed under reduced pressure to give the aldehyde 34 (99 mg, 85\%) as a clear oil. $R_{f} 0.46$ (Pet. Sp.: EtOAc 2:1); HRMS found $\left(\mathrm{M}^{+}\right)$330.1831, $\mathrm{C}_{20} \mathrm{H}_{26} \mathrm{O}_{4}$ requires 330.1831; IR (film) 2932, 1718, 1609, 1501, $1043 \mathrm{~cm}^{-1}$; ${ }^{1} \mathrm{H}$ NMR $(300 \mathrm{MHz}$, $\left.\mathrm{CDCl}_{3}\right) \delta 9.8(1 \mathrm{H}, \mathrm{s}), 7.21(1 \mathrm{H}, \mathrm{d}, J=8.8 \mathrm{~Hz}), 6.71(1 \mathrm{H}, \mathrm{dd}, J=$ $2.7 \mathrm{~Hz}, J=8.7 \mathrm{~Hz}), 6.59(1 \mathrm{H}, \mathrm{d}, J=2.8 \mathrm{~Hz}), 5.85(1 \mathrm{H}, \mathrm{ddd}, J=$ $1.9 \mathrm{~Hz}, J=5.8 \mathrm{~Hz}, J=10 \mathrm{~Hz}), 5.64(1 \mathrm{H}, \mathrm{dd}, J=1.8 \mathrm{~Hz}, J=$ $10.2 \mathrm{~Hz}), 4.29(2 \mathrm{H}, \mathrm{s}), 3.76(3 \mathrm{H}, \mathrm{s}), 3.59,3.65(2 \mathrm{H}, \mathrm{ABd}, J=9.8$ $\mathrm{Hz}), 2.97(3 \mathrm{H}, \mathrm{s}), 2.73(2 \mathrm{H}, \mathrm{m}), 2.63(1 \mathrm{H}, \mathrm{dd}, J=5.8 \mathrm{~Hz}, J=$ $17.7 \mathrm{~Hz}), 2.26,2.35$ (2H, ABdd, $J=5.9, J=12.9), 2.04(1 \mathrm{H}, \mathrm{m})$, $1.94(1 \mathrm{H}, \mathrm{dd}, J=2.1 \mathrm{~Hz}, J=13.3 \mathrm{~Hz}), 1.28(3 \mathrm{H}, \mathrm{s}) ;{ }^{13} \mathrm{C} \mathrm{NMR}$ (75 MHz, $\mathrm{CDCl}_{3}$ ) $\delta 206.6(\mathrm{C}), 157.5$ (C), 137.3 (C), 134.5 (C), 
$129.8(\mathrm{CH}), 127.9(\mathrm{CH}), 127.1(\mathrm{CH}), 112.7(\mathrm{CH}), 112.1(\mathrm{CH}), 96.0$ $\left(\mathrm{CH}_{2}\right), 72.3\left(\mathrm{CH}_{2}\right), 55.0\left(\mathrm{CH}_{3}\right), 54.9\left(\mathrm{CH}_{3}\right), 50.4(\mathrm{C}), 48.4(\mathrm{C}), 39.3$ (C), $36.5\left(\mathrm{CH}_{2}\right), 31.3\left(\mathrm{CH}_{2}\right), 19.4\left(\mathrm{CH}_{2}\right), 23.4\left(\mathrm{CH}_{3}\right) ; \mathrm{MS} m / z, 330$ (M+, 5\%), 285, 255, 227, 211, 147.

TBS Protected Enone 36. To a 50-mL round-bottomed flask was added the alcohol 22 (12.4 g, $41 \mathrm{mmol})$ and DMF (24 mL). The flask was then flushed with $\mathrm{N}_{2}$, and imidazole (102 mmol, 6.9 g) was added followed by TBDMS-Cl $(4.9 \mathrm{mmol}, 7.3 \mathrm{~g})$. The reaction was then heated to $30{ }^{\circ} \mathrm{C}$ and stirred for $18 \mathrm{~h}$. After this time, the reaction was allowed to cool and $\mathrm{Et}_{2} \mathrm{O}(100 \mathrm{~mL})$ was added. The reaction was then washed with $1 \mathrm{M} \mathrm{HCl}(100 \mathrm{~mL})$, $\mathrm{H}_{2} \mathrm{O}(3 \times 100 \mathrm{~mL})$, and brine $(100 \mathrm{~mL})$. The aqueous layers were then re-extracted with $\mathrm{Et}_{2} \mathrm{O}(2 \times 100 \mathrm{~mL})$, the combined organic layers were dried over $\mathrm{MgSO}_{4}$ and filtered, and the solvent was removed under reduced pressure to give an oil, which solidified on standing to give the silyl ether 36a (13.9 g, 81\%) as a waxy white solid. $R_{f} 0.34$ (Pet. Sp.:EA 4:1); HRMS found $\left(\mathrm{M}^{+}\right)$416.2383, $\mathrm{C}_{24} \mathrm{H}_{36} \mathrm{O}_{4} \mathrm{Si}$ requires 416.2383; IR (film) 2952, 1611, 1502, 1250, $1002,838 \mathrm{~cm}^{-1} ;{ }^{1} \mathrm{H}$ NMR $\left(300 \mathrm{MHz}, \mathrm{CDCl}_{3}\right) \delta 7.26(1 \mathrm{H}, \mathrm{d}, J=$ $8.4 \mathrm{~Hz}), 6.70(1 \mathrm{H}, \mathrm{dd}, J=2.6 \mathrm{~Hz}, J=8.8 \mathrm{~Hz}), 6.66(1 \mathrm{H}, \mathrm{d}, J=$ $2.6 \mathrm{~Hz}), 5.7(1 \mathrm{H}, \mathrm{s}), 3.82(4 \mathrm{H}, \mathrm{m}), 3.73(3 \mathrm{H}, \mathrm{s}), 3.72(1 \mathrm{H}, \mathrm{d}, J=$ $9.1 \mathrm{~Hz}, \mathrm{H} 11), 3.62(1 \mathrm{H}, \mathrm{d}, J=9.6 \mathrm{~Hz}, \mathrm{H} 11), 3.34(2 \mathrm{H}, \mathrm{m}), 2.67$ $(1 \mathrm{H}, \mathrm{d}, 14 \mathrm{~Hz}), 2.4(1 \mathrm{H}, \mathrm{m}), 2.33(1 \mathrm{H}, \mathrm{dd}, J=2.3 \mathrm{~Hz}, J=14.3$ $\mathrm{Hz}), 1.67-1.97(3 \mathrm{H}, \mathrm{m}), 0.80(9 \mathrm{H}, \mathrm{s}),-0.15(3 \mathrm{H}, \mathrm{s}),-0.19(3 \mathrm{H}$, s); ${ }^{13} \mathrm{C} \mathrm{NMR}\left(75 \mathrm{MHz}, \mathrm{CDCl}_{3}\right) \delta 157.3$ (C), $135.1(\mathrm{C}), 134.9$ (C), $133.2(\mathrm{C}), 127.6(\mathrm{CH}), 126.6(\mathrm{CH}), 111.7(\mathrm{CH}), 111.6(\mathrm{CH}), 108.5$ (C), 67.2 $\left(\mathrm{CH}_{2}\right), 64.2\left(\mathrm{CH}_{2}\right), 64.1\left(\mathrm{CH}_{2}\right), 54.8\left(\mathrm{CH}_{3}\right), 42.3,41.9$ $\left(\mathrm{C}, \mathrm{CH}_{2}\right), 31.5\left(\mathrm{CH}_{2}\right), 31.1\left(\mathrm{CH}_{2}\right), 30.5\left(\mathrm{CH}_{2}\right), 25.6\left(3 \times \mathrm{CH}_{3}\right)$, 17.9 (C), $-5.1\left(2 \times \mathrm{CH}_{3}\right) ; \mathrm{MS} \mathrm{m} / z 416\left(\mathrm{M}^{+}, 23 \%\right), 271,227,184$, 73. A $500-\mathrm{mL}$ round-bottomed flask was charged with the silyl ether 36a $(11 \mathrm{~g}, 26.4 \mathrm{mmol})$, acetone $(250 \mathrm{~mL})$, and $p$ TsOH $(2.6$ mmol, $450 \mathrm{mg}$ ). The flask was then flushed with $\mathrm{N}_{2}$ and stirred at $\mathrm{rt}$ for $1 \mathrm{~h}$, after which time TLC indicated the reaction was complete. The reaction was then poured into $\mathrm{Et}_{2} \mathrm{O}(500 \mathrm{~mL})$ before washing with $1 \mathrm{M} \mathrm{NaOH}(200 \mathrm{~mL}), \mathrm{H}_{2} \mathrm{O}(200 \mathrm{~mL})$, and brine $(200 \mathrm{~mL})$. The aqueous layers were then re-extracted with $\mathrm{Et}_{2} \mathrm{O}(2 \times 200 \mathrm{~mL})$, the combined organic layers were dried over $\mathrm{MgSO}_{4}$ and filtered, and the solvent was removed under reduced pressure. The residue was chromatographed on silica gel (Pet. Sp.:EtOAc 6:1) to give the enone $36(6 \mathrm{~g}, 61 \%)$ as a clear oil, which solidified to give a wax on standing. $R_{f} 0.24$ (Pet. Sp.:EA 4:1); HRMS found $\left(\mathrm{M}^{+}\right)$ 372.2122, $\mathrm{C}_{22} \mathrm{H}_{32} \mathrm{O}_{3}$ Si requires 372.2121; IR (film) 2930, 1669, $1610,1502,1251,1098 \mathrm{~cm}^{-1} ;{ }^{1} \mathrm{H}$ NMR $\left(300 \mathrm{MHz}, \mathrm{CDCl}_{3}\right) \delta 7.23$ $(1 \mathrm{H}, \mathrm{d}, J=8.9 \mathrm{~Hz}), 6.73(1 \mathrm{H}, \mathrm{dd}, J=2.7 \mathrm{~Hz}, J=8.7 \mathrm{~Hz}), 6.59$ $(1 \mathrm{H}, \mathrm{d}, J=2.7 \mathrm{~Hz}), 6.02(1 \mathrm{H}, \mathrm{s}), 3.89(1 \mathrm{H}, \mathrm{d}, J=9.9 \mathrm{~Hz}), 3.76$ $(1 \mathrm{H}, \mathrm{d}, J=9.8 \mathrm{~Hz}), 3.74(3 \mathrm{H}, \mathrm{s}), 2.33-2.99(7 \mathrm{H}, \mathrm{m}), 1.91(1 \mathrm{H}$, $\mathrm{dt}, J=5.5 \mathrm{~Hz}, J=14 \mathrm{~Hz}), 0.79(9 \mathrm{H}, \mathrm{s}),-0.07(3 \mathrm{H}, \mathrm{s}),-0.11$ $(3 \mathrm{H}, \mathrm{s}) ;{ }^{13} \mathrm{C} \mathrm{NMR}\left(75 \mathrm{MHz}, \mathrm{CDCl}_{3}\right) \delta 199.2(\mathrm{C}), 165.1(\mathrm{C}), 157.7$ (C), $136.7(\mathrm{C}), 132.2(\mathrm{C}), 127.7(\mathrm{CH}), 126.4(\mathrm{CH}), 112.8(\mathrm{CH})$, $112.5(\mathrm{CH}), 70.7\left(\mathrm{CH}_{2}\right), 54.9\left(\mathrm{CH}_{3}\right), 43.9(\mathrm{C}), 35.0\left(\mathrm{CH}_{2}\right), 33.7$ $\left(\mathrm{CH}_{2}\right), 31.3\left(\mathrm{CH}_{2}\right), 30.9\left(\mathrm{CH}_{2}\right), 25.54\left(3 \times \mathrm{CH}_{3}\right), 17.9(\mathrm{C}),-6.1$ $\left(2 \mathrm{xCH}_{3}\right)$; MS: $m / z, 372\left(\mathrm{M}^{+}, 52 \%\right), 342,315,227,199,115$.

$\beta$-Keto Ester 37. Freshly cleaned lithium wire (10 equiv, 13.4 mmol, $93 \mathrm{mg})$ was added to $150 \mathrm{~mL}(0.01 \mathrm{M})$ of freshly distilled ammonia in a $250-\mathrm{mL}$ three-necked round-bottomed flash at -78 ${ }^{\circ} \mathrm{C}$ (acetone/dry ice) under an atmosphere of argon. On dissolution of the lithium (approximately $10 \mathrm{~min}$ ), enone $\mathbf{3 6}(500 \mathrm{mg}, 1.34$ $\mathrm{mmol})$ in $13 \mathrm{~mL}(0.1 \mathrm{M})$ of dry $\mathrm{THF}$, containing ${ }^{t} \mathrm{BuOH}(0.9$ equiv, $1.2 \mathrm{mmol}, 114 \mu \mathrm{L}$ ), was added quickly, via syringe, to the rapidly stirred dark blue ammonia solution. After the addition was complete the syringe was rinsed with THF $(2 \mathrm{~mL})$ and this was then added to the solution. The dark blue solution was stirred for an additional 2-3 min and then quenched with the addition of isoprene until the dark blue color dissipated. The cold bath was then removed and ammonia evaporated by gently heating the flask under a stream of argon. The THF was pumped under high vacuum to ensure the ammonia was removed and then the flask was recharged with argon and THF $(20 \mathrm{~mL})$ added. The solution was then cooled to $-78^{\circ} \mathrm{C}$ (acetone/dry ice) and methyl cyanoformate (1.2 equiv, $1.6 \mathrm{mmol}$,
$130 \mu \mathrm{L}$ ) was added in a dropwise fashion. After $40 \mathrm{~min}$ TLC indicated that the reaction was complete. Cold $\mathrm{H}_{2} \mathrm{O}(5 \mathrm{~mL})$ was then added slowly and the solution was stirred for $2 \mathrm{~min}$. Cold diethyl ether $\left(-78^{\circ} \mathrm{C}, 100 \mathrm{~mL}\right)$ was added followed by the addition of cold $10 \% \mathrm{~K}_{2} \mathrm{CO}_{3}(100 \mathrm{~mL})$. The cold bath was then removed and the slurry stirred for $15 \mathrm{~min}$. The ether layer was then partitioned and washed successively with $1 \mathrm{M} \mathrm{NaOH}(50 \mathrm{~mL})$ and brine $(50 \mathrm{~mL})$. The aqueous layers were then back extracted with ether and the combined organic layers were dried over $\mathrm{MgSO}_{4}$. Removal of the ether under reduced pressure gave an orange oil, which was then columned on silica gel (Pet Sp: EA 6:1) to yield 37 (400 mg, 69\%) as a white solid. Mp 92-93 ${ }^{\circ} \mathrm{C} ; R_{f} 0.2$ (Pet. $\mathrm{Sp} .: \mathrm{EA} 4: 1$ ); MA found $\mathrm{C}$ 66.6, $\mathrm{H} 8.5, \mathrm{C}_{24} \mathrm{H}_{36} \mathrm{O}_{5} \mathrm{Si}$ requires $\mathrm{C} 66.6$, $\mathrm{H}$ 8.4; HRMS found $\left(\mathrm{M}^{+}\right)$432.2322, $\mathrm{C}_{24} \mathrm{H}_{36} \mathrm{O}_{5} \mathrm{Si}$ requires 432.2332; HRMS found $\left(\mathrm{M}^{+\bullet}-\mathrm{C}_{4} \mathrm{H}_{9}\right)$ 375.1628, $\mathrm{C}_{20} \mathrm{H}_{27} \mathrm{O}_{5} \mathrm{Si}$ requires 375.1628; IR (film) 2652, 1747, 1713, 1609, 1501, 1256, 1089 $\mathrm{cm}^{-1} ;{ }^{1} \mathrm{H}$ NMR $\delta 7.19(1 \mathrm{H}, \mathrm{d}, J=8.8 \mathrm{~Hz}), 6.68(1 \mathrm{H}, \mathrm{dd}, J=2.9$ $\mathrm{Hz}, J=8.8 \mathrm{~Hz}), 6.61(1 \mathrm{H}, \mathrm{d}, J=2.7 \mathrm{~Hz}), 4.00(1 \mathrm{H}, \mathrm{d}, J=10.5$ $\mathrm{Hz}), 3.90(1 \mathrm{H}, \mathrm{d}, J=13.2 \mathrm{~Hz}), 3.78(3 \mathrm{H}, \mathrm{s}), 3.76(3 \mathrm{H}, \mathrm{s}), 3.67$ $(1 \mathrm{H}, \mathrm{d}, J=10.5 \mathrm{~Hz}), 2.8-3.0(4 \mathrm{H}, \mathrm{m}), 2.49(2 \mathrm{H}, \mathrm{m}), 1.8(2 \mathrm{H}, \mathrm{m})$, $1.63(1 \mathrm{H}, \mathrm{m}), 0.85(9 \mathrm{H}, \mathrm{s}),-0.52(3 \mathrm{H}, \mathrm{s}),-0.66(3 \mathrm{H}, \mathrm{s}) ;{ }^{13} \mathrm{C} \mathrm{NMR}$ $\delta 206.5(\mathrm{C}), 170.8(\mathrm{C}), 158.8(\mathrm{C}), 136.9(\mathrm{C}), 133.7(\mathrm{C}), 127.3(\mathrm{CH})$, $113.5(\mathrm{CH}), 111.6(\mathrm{CH}), 68.0\left(\mathrm{CH}_{2}\right), 59.9(\mathrm{CH}), 55.1\left(\mathrm{CH}_{3}\right), 52.0$ $\left(\mathrm{CH}_{3}\right), 43.7(\mathrm{CH}), 39.7,38.4,33.8,29.3,23.6\left(\mathrm{C}, 4 \times \mathrm{CH}_{2}\right), 26.8$ $\left(3 \times \mathrm{CH}_{3}\right), 18.0(\mathrm{C}),-5.9\left(\mathrm{CH}_{3}\right),-6.0\left(\mathrm{CH}_{3}\right) ; \mathrm{MS} \mathrm{m} / \mathrm{z} 432\left(\mathrm{M}^{+}\right.$, 4\%), 375, 287, 227, 147.

MOM Enol Ether 38. To a flame-dried 50-mL round-bottomed flask was added $\beta$-keto ester $37(730 \mathrm{mg}, 1.7 \mathrm{mmol})$ and HMPA (12 mL). NaH (45 mg, $1.9 \mathrm{mmol}$ ) was added to a separate $50-\mathrm{mL}$ round-bottomed flask and the flask was flushed with $\mathrm{N}_{2}$. The HMPA solution was then slowly added to the $\mathrm{NaH}$ and the resulting solution was stirred for $4 \mathrm{~h}$. MOM-Cl $(154 \mu \mathrm{L}, 2 \mathrm{mmol})$ was then slowly added and the solution was stirred for an additional $4 \mathrm{~h}$. At this point, $\mathrm{H}_{2} \mathrm{O}(30 \mathrm{~mL})$ was slowly added and the solution was poured into $\mathrm{Et}_{2} \mathrm{O}(50 \mathrm{~mL})$ and washed with $\mathrm{H}_{2} \mathrm{O}(3 \times 50 \mathrm{~mL})$ and brine $(50 \mathrm{~mL})$. The aqueous layers were re-extracted $(2 \times 50 \mathrm{~mL})$, the combined organic layers were dried over $\mathrm{MgSO}_{4}$ and filtered, and the solvent was removed under reduced pressure to yield the ether 38 (844 mg, >95\%). $R_{f} 0.28$ (Pet. Sp.:EA 4:1); HRMS found $\left(\mathrm{M}^{+}\right)$ 476.2600, $\mathrm{C}_{26} \mathrm{H}_{40} \mathrm{O}_{6} \mathrm{Si}$ requires 476.2594; IR (film) 2951, 1728, $1608,1501,1256,1152,1090 \mathrm{~cm}^{-1} ;{ }^{1} \mathrm{H}$ NMR $\left(300 \mathrm{MHz}, \mathrm{CDCl}_{3}\right)$ $\delta 7.24(1 \mathrm{H}, \mathrm{d}, J=8.4 \mathrm{~Hz}), 6.62(2 \mathrm{H}, \mathrm{m}), 4.91(2 \mathrm{H}, \mathrm{AB}, J=6.7$ $\mathrm{Hz}), 3.80(1 \mathrm{H}, \mathrm{d}, J=9.5 \mathrm{~Hz}), 3.77(6 \mathrm{H}, \mathrm{s}), 3.46(3 \mathrm{H}, \mathrm{s}), 3.41(1 \mathrm{H}$, $\mathrm{d}, J=9.5 \mathrm{~Hz}), 2.92(2 \mathrm{H}, \mathrm{m}), 2.76(2 \mathrm{H}, \mathrm{m}), 2.37(2 \mathrm{H}, \mathrm{m}), 1.60$ $(2 \mathrm{H}, \mathrm{m}), 1.41(1 \mathrm{H}, \mathrm{m}), 0.81(9 \mathrm{H}, \mathrm{s}),-0.19(3 \mathrm{H}, \mathrm{s}),-0.27(3 \mathrm{H}, \mathrm{s})$; ${ }^{13} \mathrm{C}$ NMR $\left(75 \mathrm{MHz}, \mathrm{CDCl}_{3}\right) \delta 169.0,157.7,152.6,136.5,134.8$, 127.4, 114.6, 113.5, 110.5, 92.9, 64.1, 56.2, 55.1, 51.4, 40.4, 39.2, $28.7,27.5,25.7(3 \times), 22.5,21.4,18.1,-5.9,-6.1$; MS $\mathrm{m} / \mathrm{z} 476$ $\left(\mathrm{M}^{+}, 1 \%\right), 419,255,227,147$.

Alcohol 39. Freshly cleaned lithium ( $36 \mathrm{mmol}, 250 \mathrm{mg}$ ) was added to freshly distilled $\mathrm{NH}_{3}(200 \mathrm{~mL})$ at $-78{ }^{\circ} \mathrm{C}$ (acetone/dry ice) under an atmosphere of argon. On dissolution of the lithium, the reaction was warmed to $-40{ }^{\circ} \mathrm{C}$ and ether 38 (1.6 g, $\left.3.6 \mathrm{mmol}\right)$ in dry THF, containing $t$-BuOH $(21 \mathrm{mmol}, 2 \mathrm{~mL})$, was added in a dropwise fashion. The reaction was then allowed to reflux for 10 min and then quenched by the addition of isoprene $(200 \mu \mathrm{L})$. The ammonia was allowed to evaporate and $\mathrm{H}_{2} \mathrm{O}(20 \mathrm{~mL})$ was added, followed by EtOAc $(20 \mathrm{~mL})$. The organic layer was then washed with $\mathrm{H}_{2} \mathrm{O}(20 \mathrm{~mL})$ and brine $(20 \mathrm{~mL})$. The aqueous layers were then re-extracted with EtOAc $(2 \times 20 \mathrm{~mL})$, the combined organic layers were dried over $\mathrm{MgSO}_{4}$ and filtered, and the solvent was removed under reduced pressure. The residue was chromatographed on silica gel (Pet. Sp: EtOAc 4:1) to give the alcohol 39 (980 mg, $69 \%$ ) as a clear oil. $R_{f} 0.21$ (Pet. Sp.:EA 4:1); HRMS found $\left(\mathrm{M}^{+}\right)$ 390.2590, $\mathrm{C}_{23} \mathrm{H}_{38} \mathrm{O}_{3} \mathrm{Si}$ requires 390.2590; IR (film) 3356, 2928, $1609,1499,1249,1093 \mathrm{~cm}^{-1} ;{ }^{1} \mathrm{H}$ NMR $\left(300 \mathrm{MHz}, \mathrm{CDCl}_{3}\right) \delta 7.15$ $(1 \mathrm{H}, \mathrm{d}, J=8.7 \mathrm{~Hz}), 6.64(1 \mathrm{H}, \mathrm{dd}, J=2.8 \mathrm{~Hz}, J=8.7 \mathrm{~Hz}), 6.57$ $(1 \mathrm{H}, \mathrm{s}, J=2.8 \mathrm{~Hz}), 3.76(5 \mathrm{H}, \mathrm{m}, \mathrm{s}), 3.54(2 \mathrm{H}, \mathrm{AB}, J=9.9 \mathrm{~Hz})$, 2.83-3.00 (2H, m), $2.45(1 \mathrm{H}, \mathrm{d}, J=13.5 \mathrm{~Hz}), 2.13-2.27(1 \mathrm{H}$, 
m), 1.89-2.09 (2H, m), 1.11-1.64 (6H, m), $0.78(9 \mathrm{H}, \mathrm{s}),-0.25$ $(3 \mathrm{H}, \mathrm{s}),-0.27(3 \mathrm{H}, \mathrm{s}) ;{ }^{13} \mathrm{C} \mathrm{NMR}\left(75 \mathrm{MHz}, \mathrm{CDCl}_{3}\right) \delta 157.4,137.3$, 136.9, 128.0, 113.0, 110.9, 67.5, 62.2, 55.1, 44.1, 43.7, 40.9, 33.8, $30.5,27.7,25.8(3 \times), 24.0,18.2,18.1,-5.9,-6.1 ;$ MS $m / z 390.3$ $\left(\mathrm{M}^{+}, 2 \%\right), 333,245,227,147,126$.

Nitrile 40. The alcohol $39(980 \mathrm{mg}, 2.5 \mathrm{mmol})$ was dissolved in DCM $(20 \mathrm{~mL})$ and cooled to $0{ }^{\circ} \mathrm{C}\left(\mathrm{H}_{2} \mathrm{O} /\right.$ ice $)$. Pyridine $(4.1 \mathrm{mmol}$, $330 \mu \mathrm{L})$ was then added, followed by DMP (4.1 mmol, $1.67 \mathrm{~g})$. The reaction was then allowed to warm to rt for $3 \mathrm{~h}$, at which point TLC indicated that the reaction was complete. The reaction was then quenched by the addition of $1 \mathrm{M} \mathrm{NaOH}(5 \mathrm{~mL})$ followed by $1 \mathrm{M} \mathrm{Na}_{2} \mathrm{~S}_{2} \mathrm{O}_{3}(5 \mathrm{~mL})$, and the reaction mixture was stirred until the white precipitate had dissolved. At this point, EtOAc $(30 \mathrm{~mL})$ was added and the organic layer was washed with $1 \mathrm{M} \mathrm{NaOH} \mathrm{(20}$ $\mathrm{mL}), \mathrm{H}_{2} \mathrm{O}(20 \mathrm{~mL})$, and brine. The aqueous layers were then reextracted with EtOAc $(2 \times 20 \mathrm{~mL})$, the combined organic layers were dried over $\mathrm{MgSO}_{4}$ and filtered, and the solvent was removed to give the aldehyde 39a $(920 \mathrm{mg}, 94 \%)$ as a clear oil. $R_{f} 0.49$ (Pet. Sp.:EA 4:1); HRMS found $\left(\mathrm{M}^{+}\right)$388.2433, $\mathrm{C}_{23} \mathrm{H}_{36} \mathrm{O}_{3} \mathrm{Si}$ requires 388.2434; IR (film) 2928, 1718, 1609, 1500, 1464, 1251, $1096 \mathrm{~cm}^{-1} ;{ }^{1} \mathrm{H}$ NMR $\delta 10.05(1 \mathrm{H}, \mathrm{s}), 7.18(1 \mathrm{H}, \mathrm{d}, J=8.8 \mathrm{~Hz})$, $6.67(1 \mathrm{H}, \mathrm{dd}, J=2.9 \mathrm{~Hz}, J=8.7 \mathrm{~Hz}), 6.60(1 \mathrm{H}, \mathrm{d}, J=2.8 \mathrm{~Hz})$, $3.77(3 \mathrm{H}, \mathrm{s}), 3.60(1 \mathrm{H}, \mathrm{d}, J=10.2 \mathrm{~Hz}), 3.50(1 \mathrm{H}, \mathrm{d}, J=10.2 \mathrm{~Hz})$, $2.9(2 \mathrm{H}, \mathrm{m}), 2.6(1 \mathrm{H}, \mathrm{m}), 2.34(2 \mathrm{H}, \mathrm{m}), 2.15(1 \mathrm{H}, \mathrm{m}), 1.90(1 \mathrm{H}$, $\mathrm{m}), 1.55(2 \mathrm{H}, \mathrm{m}), 1.20-1.40(3 \mathrm{H}, \mathrm{m}), 0.81(9 \mathrm{H}, \mathrm{s}),-0.19(3 \mathrm{H}, \mathrm{s})$, $-0.27(3 \mathrm{H}, \mathrm{s}) ;{ }^{13} \mathrm{C}$ NMR $\delta 204.7,157.6,137.3,135.8,127.6,113.1$, 111.3, 66.8, 55.1, 52.1, 43.9, 41.1, 34.0, 30.7, 29.7, 25.7 (3×), 24.9, 19.2, 18.0, -5.9, -6.1; MS m/z $388\left(\mathrm{M}^{+}, 1 \%\right), 331,243,215,147$. The aldehyde 39a (920 mg, $2.4 \mathrm{mmol})$, in dry THF (24 mL), was treated with $\mathrm{NH}_{2} \mathrm{OH} \cdot \mathrm{HCl}(11.5 \mathrm{mmol}, 796 \mathrm{mg})$ and sodium acetate ( $23 \mathrm{mmol}, 1.8 \mathrm{~g}$ ) and heated at $70{ }^{\circ} \mathrm{C}$ (oil bath) for $30 \mathrm{~min}$. After this time, TLC indicated that the starting material had been consumed. The reaction was allowed to cool to rt, EtOAc $(50 \mathrm{~mL})$ was added, and the organic layer was washed with $\mathrm{H}_{2} \mathrm{O}(50 \mathrm{~mL})$ and brine $(50 \mathrm{~mL})$. The aqueous layers were then re-extracted with EtOAc $(2 \times 50 \mathrm{~mL})$, the combined organic layers were then dried over $\mathrm{MgSO}_{4}$ and filtered, and the solvent was removed under reduced pressure to give the crude oxime $\mathbf{3 9 b}(822 \mathrm{mg}, 85 \%)$ as an oil that was used without further purification. $R_{f} 0.14$ (Pet. Sp.: EA 9:1); HRMS found $\left(\mathrm{M}^{+}\right)$403.2527, $\mathrm{C}_{23} \mathrm{H}_{37} \mathrm{NO}_{3} \mathrm{Si}$ requires 403.2543; IR (film) 3326, 2928, 1725, 1609, 1499, 1249, 1096 $\mathrm{cm}^{-1} ;{ }^{1} \mathrm{H}$ NMR $\left(300 \mathrm{MHz}, \mathrm{CDCl}_{3}\right) \delta 7.68(1 \mathrm{H}, \mathrm{d}, J=4.7 \mathrm{~Hz})$, $7.21(1 \mathrm{H}, \mathrm{d}, J=8.7 \mathrm{~Hz}), 6.65(1 \mathrm{H}, \mathrm{dd}, J=2.6 \mathrm{~Hz}, J=8.9 \mathrm{~Hz})$, $6.58(1 \mathrm{H}, \mathrm{d}, J=2.2 \mathrm{~Hz}), 3.77(3 \mathrm{H}, \mathrm{s}), 3.63(2 \mathrm{H}, \mathrm{AB}, J=9.9 \mathrm{~Hz})$, $2.91(2 \mathrm{H}, \mathrm{m}), 2.66(1 \mathrm{H}, \mathrm{m}), 2.48(1 \mathrm{H}, \mathrm{m}), 2.16-2.29(2 \mathrm{H}, \mathrm{m})$, $1.97(1 \mathrm{H}, \mathrm{m}), 1.43-1.78(4 \mathrm{H}, \mathrm{m}), 1.15(2 \mathrm{H}, \mathrm{m}), 0.77(9 \mathrm{H}, \mathrm{s}),-0.22$ $(3 \mathrm{H}, \mathrm{s}),-0.25(3 \mathrm{H}, \mathrm{s}) ;{ }^{13} \mathrm{C} \mathrm{NMR}\left(75 \mathrm{MHz}, \mathrm{CDCl}_{3}\right) \delta 157.4,153.2$, 137.1, 136.3, 127.7, 113.0, 111.0, 66.4, 55.0, 44.2, 41.0, 39.7, 33.6, 30.0, 28.0, 25.7, 23.8, 18.55, 18.0, -6.0, -6.2; MS m/z $403\left(\mathrm{M}^{+}\right.$, $2 \%), 346,328,258,240$. The crude oxime 39b (240 mg, $0.58 \mathrm{mmol})$ was taken up in acetonitrile $(4 \mathrm{~mL})$, treated with $4 \mathrm{~A}$ molecular sieves $(240 \mathrm{mg} / \mathrm{mmol}, 139 \mathrm{mg})$ and $\mathrm{RuCl}_{2}[p C y m e n e]_{2}(2 \%, 7 \mathrm{mg})$, and heated to $80{ }^{\circ} \mathrm{C}$ for $10 \mathrm{~min}$. After this time the solvent was removed under reduced pressure. The residue was chromatographed on silica gel (Pet. Sp:EtOAc 9:1) to give the nitrile 40 (180 mg, $80 \%$ ) as a clear oil. $R_{f} 0.21$ (Pet. Sp.:EA 9:1); HRMS found $\left(\mathrm{M}^{+}\right)$ 385.2448, $\mathrm{C}_{23} \mathrm{H}_{35} \mathrm{NO}_{2} \mathrm{Si}$ requires 385.2437; HRMS found $\left(\mathrm{M}^{+}-\right.$ $\mathrm{CH}_{3}$ ) 370.2206, $\mathrm{C}_{22} \mathrm{H}_{32} \mathrm{NO}_{2} \mathrm{Si}$ requires 370.2202; IR (film) 2931, 2233, 1609, 1500, 1470, 1248, $1099 \mathrm{~cm}^{-1} ;{ }^{1} \mathrm{H}$ NMR $(300 \mathrm{MHz}$, $\left.\mathrm{CDCl}_{3}\right) \delta 7.16(1 \mathrm{H}, \mathrm{d}, J=8.7 \mathrm{~Hz}), 6.65(1 \mathrm{H}, \mathrm{dd}, J=2.2 \mathrm{~Hz}, J=$ $8.7 \mathrm{~Hz}), 6.60(1 \mathrm{H}, \mathrm{d}, J=1.9 \mathrm{~Hz}), 4.19(1 \mathrm{H}, \mathrm{d}, J=10.0 \mathrm{~Hz}), 3.77$ (4H, d and s), $2.95(2 \mathrm{H}, \mathrm{dd}, J=5.1 \mathrm{~Hz}, J=9.1 \mathrm{~Hz}), 2.89(1 \mathrm{H}, \mathrm{t}$, $J=4.4 \mathrm{~Hz}), 2.67(1 \mathrm{H}, \mathrm{d}, J=13.2 \mathrm{~Hz}), 2.45(1 \mathrm{H}, \mathrm{m}), 2.13(1 \mathrm{H}$, $\mathrm{d}, J=13.5 \mathrm{~Hz}), 1.82(1 \mathrm{H}, \mathrm{dt}, J=4.0 \mathrm{~Hz}, J=13 \mathrm{~Hz}), 1.60-1.79$ $(4 \mathrm{H}, \mathrm{m}), 1.09(1 \mathrm{H}, \mathrm{td}, J=4.1 \mathrm{~Hz}, J=13.0 \mathrm{~Hz}), 0.79(9 \mathrm{H}, \mathrm{s})$, $-0.19(3 \mathrm{H}, \mathrm{s}),-0.23(3 \mathrm{H}, \mathrm{s}) ;{ }^{13} \mathrm{C} \mathrm{NMR}\left(75 \mathrm{MHz}, \mathrm{CDCl}_{3}\right) \delta 157.7$, $153.2,136.5,137.8,127.8,122.3,113.2,110.8,63.8,55.1,41.9$, 41.0, 31.8, 31.0, 29.2, 28.6, $25.8(3 \times), 23.9,18.8,18.1,-5.9,-6.1$; MS $m / z, 385\left(\mathrm{M}^{+}, 2 \%\right), 370,328,254,240$.
Alkylated Nitrile 41. A flame-dried 25-mL round-bottomed flask, containing dry THF $(5 \mathrm{~mL})$, was flushed with argon and cooled to $0{ }^{\circ} \mathrm{C}\left(\mathrm{H}_{2} \mathrm{O} /\right.$ ice $)$. Diisopylamine $(1.23 \mathrm{mmol}, 174 \mu \mathrm{L})$ was then added followed by the dropwise addition of $n-\mathrm{BuLi}$ (1.6 M in hexane, $769 \mu \mathrm{L}$ ). The reaction was stirred for $15 \mathrm{~min}$ and then cooled to $-78{ }^{\circ} \mathrm{C}$ (acetone/dry ice). The nitrile 40 (190 mg, 0.49 $\mathrm{mmol})$ and dry THF $(5 \mathrm{~mL})$ were then slowly added via syringe. Once addition was complete the syringe was rinsed with dry THF $(2 \times 500 \mu \mathrm{L})$, which was added to the reaction. The flask was allowed warm to rt over $1 \mathrm{~h}$. After cooling to $-78^{\circ} \mathrm{C}$ (acetone/dry ice), MeI (1.9 mmol, $122 \mu \mathrm{L})$ added. The reaction was stirred at $-78{ }^{\circ} \mathrm{C}$ for $2 \mathrm{~h}$ and then put in the freezer $\left(-20{ }^{\circ} \mathrm{C}\right)$ overnight. Saturated $\mathrm{NH}_{4} \mathrm{Cl}(5 \mathrm{~mL})$ was added, followed by EtOAc $(20 \mathrm{~mL})$. The organic layer was washed with $\mathrm{H}_{2} \mathrm{O}(20 \mathrm{~mL}), 10 \% \mathrm{HCl}(20$ $\mathrm{mL})$, and brine $(20 \mathrm{~mL})$. The aqueous layers where then re-extracted with EtOAc $(2 \times 20 \mathrm{~mL})$, the combined organic layers were dried over $\mathrm{MgSO}_{4}$ and filtered, and the solvent was removed under reduced pressure. The residue was then chromatographed on silica gel (Pet. Sp: $\mathrm{Et}_{2} \mathrm{O}$ 9:1) to give the alkylated nitrile 41 (170 mg, $85 \%)$ as a clear oil. $R_{f} 0.60$ (Pet. Sp.:EA 4:1); HRMS found $\left(\mathrm{M}^{+}\right.$ $-\mathrm{C}_{4} \mathrm{H}_{9}$ ) 342.1887, $\mathrm{C}_{20} \mathrm{H}_{28} \mathrm{NO}_{2} \mathrm{Si}$ requires 342.1887; IR (film) 2930, 2228, 1609, 1500, 1470, 1250, $1096 \mathrm{~cm}^{-1}$; ${ }^{1} \mathrm{H}$ NMR $(300 \mathrm{MHz}$, $\left.\mathrm{CDCl}_{3}\right) \delta 7.16(1 \mathrm{H}, \mathrm{d}, J=8.7 \mathrm{~Hz}), 6.65(1 \mathrm{H}, \mathrm{dd}, J=2.7 \mathrm{~Hz}, J=$ $8.7 \mathrm{~Hz}), 6.60(1 \mathrm{H}, \mathrm{d}, J=2.8 \mathrm{~Hz}), 4.27(1 \mathrm{H}, \mathrm{d}, J=9.9 \mathrm{~Hz}), 3.77$ $(4 \mathrm{H}, \mathrm{d}$ and s), 2.89-3.07 $(2 \mathrm{H}, \mathrm{m}), 2.74(1 \mathrm{H}, \mathrm{m}), 1.72-2.19(4 \mathrm{H}$ m), $1.44(1 \mathrm{H}, \mathrm{m}), 1.43(3 \mathrm{H}, \mathrm{m}), 1.05(3 \mathrm{H}, \mathrm{m}), 0.80(9 \mathrm{H}, \mathrm{s}),-0.17$ $(3 \mathrm{H}, \mathrm{s}),-0.25(3 \mathrm{H}, \mathrm{s}) ;{ }^{13} \mathrm{C} \mathrm{NMR}\left(75 \mathrm{MHz}, \mathrm{CDCl}_{3}\right) \delta 157.7,136.2$, 136.2, 127.8, 124.6, 113.0, 110.7, 63.0, 55.1, 49.2, 41.5, 39.1, 35.4, 31.9, 28.4, 19.4, 19.4, 28.1, 25.7 (x3), 18.1, -5.9, -6.1; MS m/z $342\left(\mathrm{M}^{+}-\mathrm{C}_{4} \mathrm{H}_{9}, 52 \%\right), 315,268,254$.

Carbamate 42. To a flame-dried 50-mL round-bottomed flask was added the nitrile 41 (544 mg, $1.4 \mathrm{mmol})$ and dry THF (15 $\mathrm{mL}$ ). The flask was then fitted with a condenser and flushed with argon. $\mathrm{LiAlH}_{4}(8.2 \mathrm{mmol})$ was then slowly added and the reaction brought to reflux for $2 \mathrm{~h}$. After this time, TLC analysis indicated that all the starting material had been consumed. The reaction was cooled to $0{ }^{\circ} \mathrm{C}\left(\mathrm{H}_{2} \mathrm{O} /\right.$ ice $)$ and quenched with a few drops of a saturated solution of Rochelle salt, followed by $10 \% \mathrm{HCl}(1 \mathrm{~mL})$. $\mathrm{H}_{2} \mathrm{O}(10 \mathrm{~mL})$ was added and the mixture extracted with $\mathrm{Et}_{2} \mathrm{O}(20$ $\mathrm{mL}$ ). The organic layer was then washed with brine, dried over $\mathrm{MgSO}_{4}$ and filtered, then the solvent was removed under reduced pressure to give the crude amine $(336 \mathrm{mg}, 62 \%)$ as yellow solid that was used in the next step without further purification. The crude amine (54 mg, $0.12 \mathrm{mmol})$ was taken up in dry DCM $(2 \mathrm{~mL})$, and the flask was flushed with argon and cooled to $0{ }^{\circ} \mathrm{C}\left(\mathrm{H}_{2} \mathrm{O}\right.$, ice $)$. Triethylamine $(1.2 \mathrm{mmol}, 96 \mu \mathrm{L})$ was then added followed by methyl chloroformate $(1.2 \mathrm{mmol}, 173 \mu \mathrm{L})$ and DMAP $(5 \mathrm{mg})$. The reaction was stirred for $18 \mathrm{~h}$. After this time, $\mathrm{H}_{2} \mathrm{O}(1 \mathrm{~mL})$ was added, followed by EtOAc $(5 \mathrm{~mL})$. The organic layer was then washed with $10 \% \mathrm{HCl}(5 \mathrm{~mL}), \mathrm{H}_{2} \mathrm{O}(5 \mathrm{~mL})$, and brine $(5 \mathrm{~mL})$. The aqueous layers were re-extracted with EtOAc $(2 \times 5 \mathrm{~mL})$, the combined organic layers then dried over $\mathrm{MgSO}_{4}$ and filtered, and the solvent was removed under reduced pressure. The residue was chromatographed (Pet. Sp.:EA 6:1) to give the carbamate 42 (33 mg, $60 \%$ over 2 steps from 46 ) as a clear oil. $R_{f} 0.25$ (Pet. Sp.:EA 4:1); HRMS found $\left(\mathrm{M}^{+}-{ }^{t} \mathrm{Bu}\right) 404.2253, \mathrm{C}_{20} \mathrm{H}_{34} \mathrm{NO}_{4} \mathrm{Si}$ requires 404.2257; IR (film) 3350, 2927, 1714, 1608, 1524, 1500, 1250 $\mathrm{cm}^{-1} ;{ }^{1} \mathrm{H}$ NMR $\left(500 \mathrm{MHz}, \mathrm{CDCl}_{3}\right) \delta 7.14(1 \mathrm{H}, \mathrm{d}, J=8.8 \mathrm{~Hz})$, $6.65(1 \mathrm{H}, \mathrm{dd}, J=2.9 \mathrm{~Hz}, J=8.7 \mathrm{~Hz}), 6.56(1 \mathrm{H}, \mathrm{d}, J=2.9 \mathrm{~Hz})$, $4.82(1 \mathrm{H}, \mathrm{t}, J=5.4 \mathrm{~Hz}), 3.81(2 \mathrm{H}, \mathrm{s}), 3.76(3 \mathrm{H}, \mathrm{s}), 3.68(3 \mathrm{H}, \mathrm{s})$, $3.53(1 \mathrm{H}, \mathrm{dd}, J=7.5 \mathrm{~Hz}, 13.9 \mathrm{~Hz}), 3.14(1 \mathrm{H}, \mathrm{dd}, J=5.4 \mathrm{~Hz}, J=$ $13.9 \mathrm{~Hz}), 2.90(1 \mathrm{H}, \mathrm{dd}, J=6.1 \mathrm{~Hz}, J=16.6 \mathrm{~Hz}), 2.81(1 \mathrm{H}$, ddd, $J=3.0 \mathrm{~Hz}, J=7.7 \mathrm{~Hz}, J=17.5 \mathrm{~Hz}), 2.48(1 \mathrm{H}, \mathrm{d}, J=13.6 \mathrm{~Hz})$, $2.00(1 \mathrm{H}, \mathrm{m}), 1.85(1 \mathrm{H}, \mathrm{m}), 1.50-1.76(4 \mathrm{H}, \mathrm{m}), 1.24(1 \mathrm{H}, \mathrm{dt}, J=$ $3.9 \mathrm{~Hz}, J=13.0 \mathrm{~Hz}), 1.03(1 \mathrm{H}, \mathrm{dt}, J=3.5 \mathrm{~Hz}, J=13.3 \mathrm{~Hz}), 0.98$ $(3 \mathrm{H}, \mathrm{s}), 0.77(9 \mathrm{H}, \mathrm{s}),-0.25,-0.28(6 \mathrm{H}, \mathrm{s}) ;{ }^{13} \mathrm{C}$ NMR $(75 \mathrm{MHz}$, $\left.\mathrm{CDCl}_{3}\right) \delta 157.5(\mathrm{C}), 157.3(\mathrm{C}), 137.8(\mathrm{C}), 137.1(\mathrm{C}), 128.0(\mathrm{CH})$, $112.8(\mathrm{CH}), 111.0(\mathrm{CH}), 67.6\left(\mathrm{CH}_{2}\right), 55.1\left(\mathrm{CH}_{3}\right), 52.0,51.1(\mathrm{CH}$, $\left.\mathrm{CH}_{3}\right), 44.5,41.6,37.7\left(2 \times \mathrm{C}, \mathrm{CH}_{2}\right), 36.4\left(\mathrm{CH}_{2}\right), 34.3\left(\mathrm{CH}_{2}\right), 30.7$ 
$\left(\mathrm{CH}_{2}\right), 27.8\left(\mathrm{CH}_{3}\right), 25.8\left(3 \times \mathrm{CH}_{3}\right), 18.8,18.5,18.1\left(2 \times \mathrm{CH}_{2}, \mathrm{C}\right)$, $2 \times-6.0\left(\mathrm{CH}_{3}\right) ; \mathrm{MS} \mathrm{m} / \mathrm{z}, 404\left(\mathrm{M}^{+}-{ }^{t} \mathrm{Bu}, 57 \%\right), 316,284,241$.

1,4-Dihydoanisole 43. A three3-necked round-bottomed flask was fitted with a dry ice condenser and flame dried under vacuum. The flask was then cooled to $-78{ }^{\circ} \mathrm{C}$ (acetone, dry ice) and ammonia $(25 \mathrm{~mL})$ was then distilled into the flask. Lithium $(7.5$ mmol, $52 \mathrm{mg}$ ) was added and once the metal had dissolved the carbamate 42 (70 mg, $0.15 \mathrm{mmol})$, in dry THF $(2 \mathrm{~mL})$ and EtOH $(1 \mathrm{~mL})$, was added slowly by syringe. Once the addition was complete, the syringe was rinsed with THF $(1 \mathrm{~mL})$ and this was then added to the flask. The temperature was then raised to -40 ${ }^{\circ} \mathrm{C}$ (acetone, dry ice) and the mixture was stirred for $3 \mathrm{~h}$ at this temperature. If the blue color dissipated during this time, then more small pieces of lithium were added. After $3 \mathrm{~h} \mathrm{MeOH}(2 \mathrm{~mL})$ was slowly added, and once the blue color had dissipated the ice bath was removed and the ammonia allowed to evaporate under a stream of argon. $\mathrm{H}_{2} \mathrm{O}(5 \mathrm{~mL})$ was added, followed by $\mathrm{Et}_{2} \mathrm{O}(5 \mathrm{~mL})$, and the organic layer was then washed with $\mathrm{H}_{2} \mathrm{O}$ and brine. The aqueous layers were re-extracted with EtOAc $(2 \times 5 \mathrm{~mL})$, the combined organic layers were then dried over $\mathrm{MgSO}_{4}$ and filtered, and the solvent was removed under reduced pressure to give the crude 1,4dihydroanisole $43(70 \mathrm{mg}, \sim 100 \%)$ as a white solid, which was used immediately in the next reaction. ${ }^{1} \mathrm{H} \mathrm{NMR}\left(300 \mathrm{MHz}, \mathrm{CDCl}_{3}\right)$ key signals $\delta 4.86\left(1 \mathrm{H}\right.$, br t, $\left.-\mathrm{NHCO}_{2} \mathrm{Me}\right), 4.56(1 \mathrm{H}$, br t, H5), $3.65(3 \mathrm{H}, \mathrm{s}), 3.53(3 \mathrm{H}, \mathrm{s}), 3.08(1 \mathrm{H}, 1 \mathrm{H}, \mathrm{dd}, J=5.1 \mathrm{~Hz}, J=13.7$ $\mathrm{Hz}), 0.93(3 \mathrm{H}, \mathrm{s}), 0.84(9 \mathrm{H}, \mathrm{s}),-0.002,-0.03(6 \mathrm{H}, \mathrm{s})$.

Enone 44. To the crude 1,4-dihydroanisole 43 (500 mg, 1.1 mmol) was added $\mathrm{CDCl}_{3}(30 \mathrm{~mL})$. The solution was stirred for 2 min and then $\mathrm{Et}_{2} \mathrm{O}(50 \mathrm{~mL})$ and $1 \mathrm{M} \mathrm{NaOH}(20 \mathrm{~mL})$ were added. The organic layer was then washed with brine $(50 \mathrm{~mL})$. The aqueous layer was re-extracted with EtOAc $(2 \times 50 \mathrm{~mL})$, the combined organic layers were dried over $\mathrm{MgSO}_{4}$ and filtered, and the solvent was removed under reduced pressure to give an oil. The oil was chromatographed on silica gel (Pet. Sp:EA 6:1 to 2:1) to give the aromatic compound $\mathbf{4 2}(80 \mathrm{mg}, \mathbf{1 6 \%})$ and the $\alpha, \beta$-enone $\mathbf{4 4}(300$ $\mathrm{mg}, 60 \%$ ) as a clear oil. $R_{f} 0.27$ (Pet. Sp.:EA 2:1); HRMS Found $\left(\mathrm{M}^{+\bullet}-{ }^{t} \mathrm{Bu}\right.$ ) 392.2245, $\mathrm{C}_{21} \mathrm{H}_{34} \mathrm{NO}_{4} \mathrm{Si}$ requires 392.2257; IR (film) 3342, 2929, 1718, 1666, $1547 \mathrm{~cm}^{-1} ;{ }^{1} \mathrm{H}$ NMR (300 MHz, $\mathrm{CDCl}_{3}$ ) $\delta 5.80(1 \mathrm{H}, \mathrm{s}), 4.61(1 \mathrm{H}, \mathrm{br} \mathrm{s}), 3.75(1 \mathrm{H}, \mathrm{dd}, J=3.8 \mathrm{~Hz}, J=15.4$ $\mathrm{Hz}), 3.66(3 \mathrm{H}, \mathrm{s}), 3.61(2 \mathrm{H}, \mathrm{s}), 3.01(1 \mathrm{H}, \mathrm{dd}, J=5.6 \mathrm{~Hz}, J=13.7$ $\mathrm{Hz}), 1.40-2.60(16 \mathrm{H}, \mathrm{m}), 0.96(3 \mathrm{H}, \mathrm{s}), 0.83(9 \mathrm{H}, \mathrm{s}), 0.01(6 \mathrm{H}, \mathrm{s})$; ${ }^{13} \mathrm{C}$ NMR (300 MHz, $\left.\mathrm{CDCl}_{3}\right) \delta 199.6$ (C) 166.5 (C), $157.4(\mathrm{C})$, $124.7(\mathrm{CH}), 63.9\left(\mathrm{CH}_{2}\right), 54.4\left(\mathrm{CH}_{-3}\right), 51.9(\mathrm{CH}), 51.3(\mathrm{CH}), 43.4$ $\left(\mathrm{CH}_{2}\right), 42.5(\mathrm{C}), 37.9(\mathrm{C}), 37.1\left(\mathrm{CH}_{2}\right), 35.9\left(\mathrm{CH}_{2}\right), 35.7\left(\mathrm{CH}_{2}\right), 34.9$ $\left(\mathrm{CH}_{2}\right), 27.7\left(3 \times \mathrm{CH}_{3}\right), 25.6(\mathrm{C}), 21.6\left(\mathrm{CH}_{2}\right), 20.8\left(\mathrm{CH}_{2}\right), 18.7$ $\left(\mathrm{CH}_{2}\right), 17.8(\mathrm{C}), 2 \times-5.9\left(\mathrm{CH}_{3}\right)$; $\mathrm{MS} \mathrm{m} / z 392\left(\mathrm{M}^{+}-{ }^{t} \mathrm{Bu}, 55 \%\right)$, $279,167,149$.

Dienone 45. The enone 44 (66 mg, $0.15 \mathrm{mmol})$ was dissolved in benzene $(5 \mathrm{~mL})$ and conc $\mathrm{HCl}$ ( 3 drops) was added. The reaction was stirred rapidly and DDQ $(0.16 \mathrm{mmol}, 36 \mathrm{mg})$, dissolved in benzene $(2 \mathrm{~mL})$, was added in a dropwise fashion, allowing the yellow color to dissipate between drops. Once the addition was complete, the reaction was allowed to stand for $1 \mathrm{~min}$ and then the benzene was removed by pipet taking care to avoid conc $\mathrm{HCl}$ drops at the bottom of the flask. Once the benzene was removed the conc $\mathrm{HCl}$ drops were washed with benzene $(2 \times 1 \mathrm{~mL})$, the reaction mixture was loaded onto an alumina column $(2 \mathrm{~g})$, and the benzene was eluted. The dienone was then eluted (by gradient of $1 \%$ EtOAc/ Pet. Sp to 5\% EtOAc/Pet. Sp) to afford dienone 45 (47 mg, 70\%) as a clear oil. $R_{f} 0.25$ (Pet. Sp.:EA 2:1); HRMS found $\left(\mathrm{M}^{+\bullet}\right)$ 447.2808, $\mathrm{C}_{25} \mathrm{H}_{41} \mathrm{NO}_{4} \mathrm{Si}$ requires 447.2805; IR (film) 3362, 2928, $1715,1660 \mathrm{~cm}^{-1} ;{ }^{1} \mathrm{H}$ NMR $\left(300 \mathrm{MHz}, \mathrm{CDCl}_{3}\right) \delta 6.32(1 \mathrm{H}, \mathrm{d}, J=$ $9.6 \mathrm{~Hz}), 6.21(1 \mathrm{H}, \mathrm{dd}, J=9.9 \mathrm{~Hz}, J=3.2 \mathrm{~Hz}), 5.81(1 \mathrm{H}, \mathrm{s}), 4.81$ $(1 \mathrm{H}, \mathrm{m}), 3.67(3 \mathrm{H}, \mathrm{s}), 3.64(2 \mathrm{H}, \mathrm{s}), 3.46(1 \mathrm{H}, \mathrm{dd}, J=8.1 \mathrm{~Hz}, J=$ $14 \mathrm{~Hz}, \mathrm{H} 12), 3.10(1 \mathrm{H}, \mathrm{dd}, J=5.5 \mathrm{~Hz}, J=14.1 \mathrm{~Hz}), 1.05-2.60$ $(12 \mathrm{H}, \mathrm{m}), 1.04(3 \mathrm{H}, \mathrm{s}), 0.84(9 \mathrm{H}, \mathrm{s}), 0.01,-0.96(6 \mathrm{H}, \mathrm{s}) ;{ }^{13} \mathrm{C} \mathrm{NMR}$ $\left(75 \mathrm{MHz}, \mathrm{CDCl}_{3}\right) \delta 200.2(\mathrm{C}), 157.6(\mathrm{C}), 157.4(\mathrm{C}), 137.2(\mathrm{CH})$, $129.7(\mathrm{CH}), 125.0(\mathrm{CH}), 61.8\left(\mathrm{CH}_{2}\right), 54.9\left(\mathrm{CH}_{3}\right), 52.1(\mathrm{CH}), 51.2$ $(\mathrm{CH}), 44.5\left(\mathrm{CH}_{2}\right), 42.7(\mathrm{C}), 38.2(\mathrm{C}), 37.4\left(\mathrm{CH}_{2}\right), 36.4\left(\mathrm{CH}_{2}\right), 32.9$ $\left(\mathrm{CH}_{2}\right), 27.1\left(\mathrm{CH}_{3}\right), 25.8\left(3 \times \mathrm{CH}_{3}\right), 22.9\left(\mathrm{CH}_{2}\right), 18.5\left(\mathrm{CH}_{2}\right), 18.0$ (C), $-5.7\left(2 \times \mathrm{CH}_{3}\right)$; MS m/z $447\left(\mathrm{M}^{+} \bullet, 3 \%\right), 390,366,346$.

Pyrrolidine 46. The dienone 45 (47 mg, $0.1 \mathrm{mmol}$ ) was taken up in dry DCM $(1 \mathrm{~mL})$ and treated with $\mathrm{FeCl}_{3}(10 \%, 2 \mathrm{mg})$, following which the reaction went a deep green. TMS-Cl $(0.1 \mathrm{mmol}$, $12 \mu \mathrm{L}$ ) was then slowly added and the reaction instantly changed to a yellow color. After $10 \mathrm{~min}$, TLC indicated that most of the starting material had been consumed. $\mathrm{H}_{2} \mathrm{O}(1 \mathrm{~mL})$ followed by EtOAc $(5 \mathrm{~mL})$ were added and the organic layer was washed with $1 \mathrm{M} \mathrm{NaOH}(5 \mathrm{~mL})$ and brine $(5 \mathrm{~mL})$. The aqueous layers were re-extracted with EtOAc $(2 \times 5 \mathrm{~mL})$, the combined organic layer was dried over $\mathrm{MgSO}_{4}$ and filtered, and the solvent was removed under reduced pressure. The residue was chromatographed on silica gel (Pet. Sp: EA 6:1) to give the dienone $45(9 \mathrm{mg}, 19 \mathrm{mg})$ and the $\alpha \beta$-enone $46(10 \mathrm{mg}, 21 \%) . R_{f} 0.20$ (Pet. Sp.:EA 2:1). HRMS found $\left(\mathrm{M}^{+\bullet}\right)$ 447.2812, $\mathrm{C}_{25} \mathrm{H}_{41} \mathrm{NO}_{4} \mathrm{Si}$ requires 447.2805; IR (film) 2953, 1701, 1675, 1449, $1388 \mathrm{~cm}^{-1}$; ${ }^{1} \mathrm{H}$ NMR $\left(500 \mathrm{MHz}, 100{ }^{\circ} \mathrm{C}\right.$, DMSO- $\left.d_{6}\right) \delta 5.75(1 \mathrm{H}, \mathrm{s}), 4.09(1 \mathrm{H}, \mathrm{ddd}, J=8.3 \mathrm{~Hz}), 3.65(1 \mathrm{H}$, $\mathrm{d}, J=11.2), 3.60(3 \mathrm{H}, \mathrm{s}), 3.58(1 \mathrm{H}, \mathrm{d}), 3.28(1 \mathrm{H}, \mathrm{d}, J=10.7)$, $3.16(1 \mathrm{H}, \mathrm{d}, J=11.2 \mathrm{~Hz}), 3.12(1 \mathrm{H}, \mathrm{dd}, J=8.8 \mathrm{~Hz}), 2.75(1 \mathrm{H}$, $\mathrm{dd}, J=6.5 \mathrm{~Hz}, J=19.5 \mathrm{~Hz}), 2.32(1 \mathrm{H}, \mathrm{m}), 2.18(2 \mathrm{H}, \mathrm{m}), 2.02-$ $2.13(2 \mathrm{H}, \mathrm{m}), 1.80(1 \mathrm{H}, \mathrm{m}), 1.70(1 \mathrm{H}, \mathrm{m}), 1.68(1 \mathrm{H}, \mathrm{d}, J=8.3$ $\mathrm{Hz}), 1.55(2 \mathrm{H}, \mathrm{m}), 1.38(1 \mathrm{H}, \mathrm{m}), 1.06(1 \mathrm{H}, \mathrm{m}), 1.04(3 \mathrm{H}, \mathrm{s}, \mathrm{H} 13)$, $0.85(9 \mathrm{H}, \mathrm{s}), 0.01,-0.01(6 \mathrm{H}, \mathrm{s}) ;{ }^{13} \mathrm{C} \mathrm{NMR}\left(125 \mathrm{MHz}, 75{ }^{\circ} \mathrm{C}\right.$, DBenzene- $\left.d_{6}\right) \delta 196.4,162.6,156.0,127.4,63.3,59.5,55.7,53.5$, 52.0, 52.1, 40.0, 39.3, 36.6, $31.7(2 \times), 30.2,29.3(2 \times), 26.0,25.6$ $(3 \times), 18.3,-5.7,-5.8$; MS m/z $447\left(\mathrm{M}^{+} \bullet, 3 \%\right), 390,360,338$, 256.

Acknowledgment. We thank Bruce Twitchin (RSC, ANU) for his synthetic expertise. O.E.H. thanks the Australian National University for an ANU Ph.D. scholarship.

Supporting Information Available: General experimental and spectra data. This material is available free of charge via the Internet at http://pubs.acs.org.

JO701995U 